University of Rhode Island

DigitalCommons@URI

Open Access Dissertations

1991

\title{
Great Expectations: A Workshop on Responsible Dating
}

Rita C. Chrappa

University of Rhode Island

Follow this and additional works at: https://digitalcommons.uri.edu/oa_diss

\section{Recommended Citation}

Chrappa, Rita C., "Great Expectations: A Workshop on Responsible Dating" (1991). Open Access

Dissertations. Paper 910.

https://digitalcommons.uri.edu/oa_diss/910

This Dissertation is brought to you for free and open access by DigitalCommons@URI. It has been accepted for inclusion in Open Access Dissertations by an authorized administrator of DigitalCommons@URI. For more information, please contact digitalcommons-group@uri.edu. 


\section{GREAT EXPECTATIONS: A WORKSHOP \\ ON RESPONSIBLE DATING}

BY

RITA C. CHRAPPA

A DISSERTATION SUBMITTED IN PARTIAL FULFILLMENT OF THE REQUIREMENTS FOR THE DEGREE OF DOCTOR OF PHILOSOPHY

IN PSYCHOLOGY

UNIVERSITY OF RHODE ISLAND 1991

$$
2678354
$$


Abstract

This study was designed to investigate whether a 50-minute workshop educating students in the areas of rape and rape myths would have an effect on attitudes and knowledge about responsible dating.

Great Expectations is a 50-minute workshop which incorporates both a lecture and an affective component in its approach to educating students. Itg focus is on educating students around responsible dating as well as rape and rape myths.

The sample was made up of $150 \mathrm{high}$ school seniors, 75 of whom participated in the workshop and 75 served as a control group. Three measures -- Rape Myth Acceptance, Knowledge of Rape and Rape Myths, and Scenarios which judged whether an incident is a rape -- were administered both pretest and post-test. All students were administered these measures by their classroom teacher one week before and one week after the workshop.

Results showed that there were no significant differences between the treatment and control groups on post-test measures. All groups improved on knowledge whether they were involved in the workshop or not, suggesting that 1) the importance of looking into the sensitizing effects of the measures being used, and 2) the importance of exploring what impact the spread of effects may have played in these results. Women scored higher than men on knowledge-based questions both pretest and post-test. The information obtained continues to demonstrate gender differences between men and women in their knowledge of rape, and acceptance of rape myths. 


\section{Acknow ledgements}

The completion of this dissertation marks an end to a graduate school career that has been positively impacted on by many people.

Dr. William Vosbough has provided me with an understanding of and appreciation for working with systems. His spirit and commitment towards enhancing psychological support services within schools has been especially invaluable and something that will always be an asst for me.

Dr. John Stevenson's knowledge of personality theory as well as methodology and evaluation programs has contributed significantly in supporting this project as well as in my overall development as a researcher and clinician.

I would like to thank Dr. Thomas Gunning for his ongoing support and enthusiasm in helping to facilitate the progress of this project; and for his commitment to working in, and providing quality programs within school systems.

Dr. Stuart Vyse, dear friend, tutor, colleague and highly skilled statistician has been an ongoing support for many years. His patience and ability to make the most complex understandable is remarkable and for this I have the utmost appreciation and gratitude.

Dr. Grace Frenzel and Dr. Mark Goldman have been true friends for many years and I am grateful to them for the roles they played in working on this project as well as in the more direct role they played by serving as the outside members at my defense. Their humor and tender loving care helped to get me through those especially tough times.

I am very grateful for the support and open mindedness of Ann Mack, for allowing me to incorporate the Great Expectations workshop into her curriculum. I also appreciate the time she spend evaluating and giving me feedback in the initial planning phase of this project. This feedback along with such incredible support from Ann contributed significantly to how smoothly the project ran. I am ever grateful for having met Ann. 
Dr. Kent Yrchik-Shoemaker and his wife Debbie who have been gupportive in so many ways, it's hard to know where to begin acknowledging them. They have provided me with a home on my many trips to Rhode Island, as well as with enthusiasm and support to hang in when the end seemed so far off. I would especially like to thank Kent for serving as my co-leader in running the Great Expectations workshop; and for using a vacation day to do so. I appreciate his comitment to this project.

Dr. Lori Huckel was the person who initially got me interested in the area of acquaintance rape. Her energy and commitment to educating students in this and in other areas is quite remarkable. Lori was not only the spark that gave birth to this workshop but the energy that helped to keep it going. I appreciate all her help and support as a good friend and colleague. Her husband Rob Bauer and children Nathan, Amelia and zac have supported my equally in this project and have alwayg welcomed me with open arms when I needed them. A big thank you to them all.

The support and understanding I have received from my colleagues at Dedham Medical Associates cannot go unrecognized. Their great encouragement to persist and finish up has been well taken.

I truly appreciate and am ever grateful to my friend of 30 years, Nancy Lenhart, her husband John and three children, Kerrie, Patrick, and colleen. Their many cards, messages on my machine and long conversations of encouragement mixed with pride over my accomplishments have been deeply appreciated.

My dear friends Drs. John and Lois Goodman offered me tremendous support as well as their expertise in being two of my editors. They have been behind me throughout this project even though at times that may have been a difficult place to be. I do so appreciate their loyalty and friendship.

I would especially like to thank both Jeanne and Amy Goodman for their unconditional love, support, and sense of humor which has at times 
been the spark that has kept me going.

Terri Hodson has been truly remarkable in setting up the APA style and standards in typing up this dissertation. She has contributed many pressure filled hours of her time when I've had to meet deadlines, while always reassuring me it could be fine. Finding Terri was like a gift from the heavens, and I'm glad she came my way.

My parents Anna and Carl, have offered the a tremendous amount of support; especially financial, throughout my graduate school career. They have always been there when I needed them and I know they share my pride and joy at having finished my doctoral work. My sister catherine, while pursuing her career in law school, has continued to be incredibly supportive and proud of my accomplishments. Her endless cards and letters showing support while adding humor to my life have been most helpful during stressful times. Although my brother carl is miles away, when he has the opportunity, he never forgets to encourage and support the work I'm doing.

It is with the greategt pleasure that I how have the opportunity to not only acknowledge but to dedicate this dissertation to two very special people in my life; Dr. Janet Kulberg and Dr. Judy Birnbaum. Janet has played a significant role in my graduate career as major professor, mentor nd friend. Her support throughout my years at the University of Rhode Island has made the experience both enriching and rewarding. I only hope that in my role as clinician I might be as eupportive responsive and caring of those who look to me for direction as Janet has been. It is with my deepest gratitude that I have the pleasure to acknowledge such a unique individual.

Judy has played a significant role of a different nature in my life. She has taught me that as adultg we have the power to deal with situations in ways we never felt possible growing up. Judy has nurtured and guided me through some very tough times but has also shared in the joys and happiness of the good times. She has enabled me to push through and beyond that which at times has felt impossible to 
accomplish. It is her strength of her love and the consistency of her support over many years that has enabled me to persist and achieve at this level. It's important that I not forget, however, that Judy and I have been fortunate enough to have had the help of five others in accomplishing what needed to be done. It is the combination of Judy and their strength, love support, creativity, and persistence that I am where I am today. To Judy and our group, my deepest gratitude for your love and support. 
Abstract . . . . . . . . . . . . . . . . . . . . . . . ii

Acknowledgements . . . . . . . . . . . . . . . . . . . . . ili

Chapter

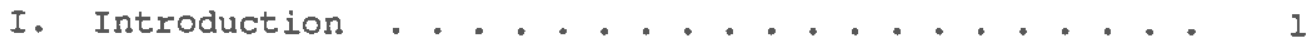

Statement of Problem . . . . . . . . . . . . . . 1

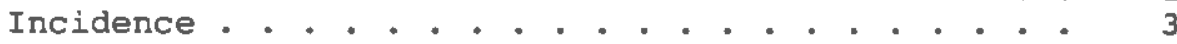

Attitudea . . . . . . . . . . . . . . . . . . . 5

Characteristics of Victims and Perpetrators . . . . 8

Effortg to Educate .................. . . 11

Justification for the Intervention . . . . . . . . 12

Conclusion . . . . . . . . . . . . . . . . . . 15

II. Methodg. . . . . . . . . . . . . . . . . . . . . 16

Subjects . . . . . . . . . . . . . . . . . . 16

Instruments ........................ . . . 17

Procedure........................ . . . 21

Workshop ....................... . 21

III. Regults. . . . +. . . . . +. . . . . . . . . 23

Summary Data . . . . . . . . . . . . . . . . 23

Preliminary Analyses . . . . . . . . . . . . . . 25

Effects of Treatment . . . . . . . . . . . . . 26

Reliability and Intercorrelation of Measures . . . 28

Relationship Between Dating Behavior and Test scores 30

IV. Digcussion . . . . . . . . . . . . . . . . . . . 32

Future Directions . . . . . . . . . . . . . . . . 36

Conclusions ........................ 36

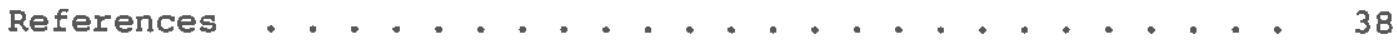

Appendices . . . . . . . . . . . . . . . . . . . . . . . 41

A. Demographics . . . . . . . . . . . . . . 41

B. Rape Myth Acceptance Scale . . . . . . . . . . 42

c. Scenarios................... . . 44

D. Knowledge Scale... . . . . . . . . . . . 45

E. Great Expectations Workshop . . . . . . . . . . 47

Bibliography . . . . . . . . . . . . . . . . . . . . . 63 
CHAPTER I

Introduction

\section{Statement of Problem}

In American society, women, including adolescent women, experience sexual assault and rape relatively commonly. In one study of 3,187 women, one out of eight reported having been raped. Of those raped, three-quarters were between the ages of 15 and 21 (Koss, Gidycz, \& Wisniewski, 1987). Kanin and Parcell's (1977) research showed that 83\% of women surveyed had experienced some form of sexually offensive male aggression during their dating history. Further research conducted by Burkhart and Stanton (1985) reported that only $4 \%$ of 253 college women surveyed did not experience any incidence of aggression during their dating history.

Some surveys done with men are even more striking. Kanin (1967, 1969) reported that $25.5 \%$ of 341 men reported at least one episode of having made forced attempts to have sex while observing their date crying, screaming, or fighting to get away. Burkhart has reported, in further research, that males have accepted responsibility for using a variety of intrusive and aggressive sexual acts against a women's wishes (Rapport \& Burkhart, 1984).

In their book, No Is Not Enough: Helping Teenagers Avoid Sexual Assault, Adams, Fay and Loreen-Martin (1985) report that at least onethird of teens are involved in some form of coercive sexual experience during high school years. Koss (1987) reported that in her study, three-quarters of women who reported having been raped were between the ages of 15 and 21 .

In a preliminary study done by the National Center for the Prevention of Rape, 928 of teenage victims said they were acquainted with their attacker (Seligman, Huck, Joseph, Namuth, Prout, Robinson, \& McDaniel, 1984). In our culture, we often think that only a sinister, masked person in some alley commits rape. However, people must learn 
that rape occurs whenever a male coerces a woman into having sexual intercourse without consent, even if the man knows the woman he is dating.

In trying to explain the roots of this violence, many investigators have pointed out the prevalence in our culture of stereotypes and myths that tend to perpetuate sexual violence. For example, one myth suggests that men are supposed to be aggressive and dominating. Another myth suggests that women don't really say what they mean, concluding that a no from a woman is really a yes. Women, on the other hand, are supposed to be submissive and should act shy and/or coy (Bell, 1980). Donnerstein and Berkowitz (1982) report strong evidence that supports the causality between myths and greater violence. They found that men displayed greater violence toward women when men were led to believe it was permissible. It was also noted that when men were exposed to materials that suggested women find sexual aggression desirable, men were less likely to take responsibility for any kind of sexual assault. This constellation of beliefs implies that women are responsible for the occurrence and prevention of rape. The results are twofold: (1) men are encouraged to forego accepting responsibility for these crimes; and (2) women think that the incidents are their responsibility and are reluctant to report them.

Myths and misinformation about who is likely to rape appear to contribute to the perpetuation of acquaintance rape. Lack of accurate knowledge is a factor in the perpetuation of myths and misinformation. Therefore, addressing this lack of knowledge through education appears to be a logical approach to reducing the prevalence of myths and misinformation that contribute to acquaintance rape.

How to educate our youth about these issues becomes a major question. How do we provide students with the information they need to act responsibly in dating relationships? How do we dispel the myths passed on from one generation to the next? 
Our educational system now requires most schools to offer health education classes. After having interviewed approximately 200 students in the 11th and 12th grades, the author found that these classes are considered beneficial but neglect the topic of dating relationships. These classes are mostly designed to educate students about sexuality, anatomical differences between men and women, sexually transmitted diseases, and drugs. While we acknowledge the importance of drug education, we need to teach students to say no and to take no as a valid answer in dating relationships, as well.

This study is based on the hypothesis that a 50-minute workshop which addresses areas related to expectations in dating and communication styles might increase knowledge and dispel myths and subsequently, might lead to responsible dating behavior.

A more complete review of the literature on the incidence of acquaintance rape, attitudes of both victims and perpetrators toward rape and rape myths, characteristics of both victims and those who are likely to victimize, and efforts to educate high school students about these issues, will be covered in the upcoming section to support the undertaking of this project.

\section{Incidence}

Although most of the initial studies of courtship violence were done with small samples, such studies have sparked further work in the area. As early as 1957, Kirkpatrick and Kanin were doing research in the area of coercive experiences to which college women were being subjected. In their study of 291 college women, 55.78 had been offended at some level of sexual intimacy in the prior year. Twenty years after this initial study, Kanin and Parcell (1977) repeated this research and found that $83 \%$ of the women ourveyed reported having experienced some sexually offensive male aggression during their dating history. Mary P. Koss and her associates directed a national study on the 
incidence and prevalence of sexual aggression and victimization among college students. The study showed that fifty-two percent of the women surveyed had experienced some form of victimization. Of the 3,187 women surveyed, one out of every eight reported having been raped. Of those, three-quarters of the women were between the ages of 15 and 21 at the time that the rape occurred with a mean age of 18 . Forty-geven percent of those women who had been raped reported that they were raped by first or casual dates, or by romantic acquaintances (Koss, Gidycz, \& Wisniewski, 1987).

skelton (1982) surveyed a population closely resembling those described above, and found that only 48 reported No aggressive incidents during their courtship history.

In addition to interviews and surveys of women, one can study the prevalence of male sexual aggression through the use of self-reports. Kanin $(1967,1960)$ found that, of 341 men who reeponded to her survey, 87 (25.5\%) reported at least one episode of having made forceful sexual attempts and that these attempts had caused distress in women manifested in their crying, screaming, and fighting. In yet another survey done, the following information was gained through the use of self-report by 201 male undergraduate students. "They found that only 298 of the sample denied any form of sexually aggressive behaviors and $15 \%$ had intercourse with a woman against her will" (Burkhart \& stanton, 1985, p. 7). It was also noted that $61 \%$ had fondled a woman's breast against her will, 428 had removed or tried to take off a woman's clothea against her will, and $37 \%$ had touched a woman's genitals against her will (Burkhart \& stanton, 1985). Among 1,846 male undergraduate students, Koss and Oros (1982) reported a high frequency of self-reported sexual aggression which came in the form of gaining sex through coercive pressure (15\%) and/or by saying things that were not true (198) (Koss \& Oros, 1982). L'Armond and Pepitone (1982) found that a rape was judged less serious in proportion to the length of time a victim knew her 
perpetrator. In fact, if a victim knew her perpetrator, it was highly likely that an agsault would not even be considered a rape (Klemmack \& Klemmack, 1976; Oros, Leonard, \& Koss, 1980). Klemmack and Klemmack (1980), using female subjects, looked at the issue of the relationship between victims and their assailants. They found that if any relationship exists between the victim and her assailant the number of people who consider an incident rape decreases by 50\%. However, women who would not consider the above degcribed incident rape would consider a similar situation rape if the person did not know the assailant or have any previous interactions with him.

\section{Attitudes}

Since the initial work of Kirkpatrick and Kanin (1957), our society is becoming more aware of the frequency and atrocity of acquaintance rape among our young adults. However, we also need to learn about the factors contributing to such a crime. Brownmiller (1975) in her book, Against our Will: Men, women and Rape clearly demonstrates that our culture condones rape. She states that our society perpetuates the following myths: 1) All women want to be raped; 2) A woman cannot be raped if she really doesn't want to; and, 3) If a woman is raped, it is because she asked for it (Brownmiller, 1975). Burt (1980) reported that over half of her sample agreed with such statements as, "A woman who goes to the home or apartment of a male on a first date implies she wants to have sex," and "In a majority of rapes, the victim was promiscuous or had a bad reputation" (Burt, 1980, p. 229).

The myth of the rapist being a stranger and/or some crazed person continues to persist even when it is reported that, in the majority of cases, the victims know their assailant. These myths, and others, persist from generation to generation in our culture. The National Center for the Prevention of Rape reported in a preliminary study that 
928 of teenage victins were acquainted with their assailant (Seligman, Huck, Joseph, Namuth, Prout, Robinson, \& McDaniel, 1984).

Although the legal definition of rape varies from one state to the next, three major elements are consistently incorporated in the definition: 1. carnal knowledge of a woman, defined as sexual penetration, 2. lack of consent to this carnal knowledge, and 3 . use of force or threat of force to accomplish the act (Burkhart stanton, 1985). The New Webster's Dictionary (1974) defines rape as "Sexual intercourse by force; an outrageous violation." It should be noted that consent is active and not passive. Therefore, it should be assumed that sex is not an option unless active consent is given.

What is an acquaintance? What is a friend? The dictionary tells us that these are people we either slightly know or people that are known and liked by another (Bolander \& stodden, 1986). If we consider rape as an outrageous violation, the words acquaintance rape are a contradiction in terms. The complexity of the term acquaintance rape and confusion associated with knowing a perpetrator makes the crime that much more difficult to report to others and to accept as having taken place. Koss and associates found in her surveys a strong correlation between being romantically involved with a person and not acknowledging that one has been a victim of a rape (Koss, Gidycz, \& Wisniewski, 1987). Kogs and Oros (1982) found that most college age women who have been forced into intercourse by an acquaintance do not define it as rape. It has been noted, however, that in the college population, sexual aggression is relatively rare among strangers, more often than not, the victim has had some level of courtship relationship with the offender. Andrea Parrot interviewed women students at cornell University who, when asked "Have you ever been raped?", replied "No." However, when she then asked, "Have you ever been involved in a coercive sexual encounter?", the same student would reply, "Yes" (Sweet, 1985). It's important to note that in many ways, acquaintance rape may 
have more psychologically damaging effects than other forms of sexual assault. "The feelings that a rape gurvivor expresses -- shame, guilt, fear, disbelief, lower self-e日teem, are often even stronger in the case of acquaintance rape in part because the rapist was someone ohe believed would not harm her" (Ehrart \& Sandler, 1985). A woman may, therefore, deny the rape, and the incident goes unreported. Acquaintance rape may contribute to a lack of trust among friends and impact negatively on one's own belf-trust (Ehrart \& sandler, 1985).

The incidence of acquaintance rape is shocking to many, yet it comes as no surprise to others. Our culture has created myths that are perpetuated from generation to generation. Women have been taught that they are not supposed to show their sexual desires, while men have been taught to take the initiative and persist even when they are told to stop (Check \& Malamuth, 1983). Why? Because men have been taught that when a woman is saying no it's only because that's what she ig supposed to say. Women aren"t supposed to be interested in such things. What if a woman show interest in a man? Does that interest alone imply permission for sexual aggre日sion? Abbey (1982) showed that, in fact, men most often misinterpret women's friendliness in bocial situations as a sign of sexual interest. Through our sex role training of both men and women, we imply that men must prove their manhood and that women must prove their womanhood. Proof takes place when (men) boys try to have sex whether they want it or not and when women resist sex whether they want it or not (campbell, not dated.).

It would appear that there might be some characteristics to delineate those who are victims and those who victimize. It is expected that these factors would relate to both attitudes and incidence: 
Characteristics of Victims and Perpetrators

Minimal research efforts have delineated characteristics of victims and offenders. Kanin and associates, doing similar studies in 1957 and 1977 , found that there were very few important differences between offended and non-offended women. What they did see overall, however, was that women who had reported having been victimized within the last year were more likely to have an overall history of being sexually victimized than non-offended women (Kanin \& Kirkpatrick, 1957; Kanin \& Parcel, 1977). That victimization, in itself, often predicts further victimization is a familiar concept to those involved in victimization research. In a study by Korman and Leslie (1982), among college women who had been offended, the mean number of victimizations was 5.7 (Burkhart \& Stanton, 1985).

Surveying 263 undergraduate women, Skelton (1982) investigated the correlates of victimization experiences. Among several measures administered were demographic variables, dating history, sexual history, sexual communication style, Burt's (1980) rape beliefs measures, locus of control, gelf-esteem, assertiveness, and ratings by students of their usual and ideal dating partners on the Bem Sex Role Inventory. Skelton used the information gathered in many regression procedures as predictors of two criteria: (a) the number of experiences where the student had been a victim in the past six months and (b) the highest level of sexual aggression occurring during the individual's dating history (Skelton, 1982). These analyses of the data revealed that the number of victimization incidents was impacted by the following, in order of significance: (1) the victim's score on Burt'a (1980) Adversarial Sexual Beliefs Scale, a scale that measures an individuals expectations that relationships are exploitive and not to be trusted; (2) the number of dating partners; (3) the Bem Sex Role Inventory, a masculinity scale score for usual dating partner; 4) self-esteem; and (5) the assertion scale. Self-esteem and assertion were negatively 
correlated with the number of victimizations, while the others were positively correlated. The multiple $R$ for the five predictors was .36. The small amount of variance (148) accounted for makes it difficult to predict victimization. However, the significant relationship among these variables suggests vulnerability to be victimized.

Significant relationships with the highest level of sexual aggression sustained, in order of significance, were: (1) the number of sexual partners in the previous six months; (2) the number of dating relationships in the previous six months; (3) the score on Ben Sex Role Scale; (4) the number of dates in the previous month; and (5) one's reliance on nonverbal means of communication for sexual consent. All five predictors were significant with a multiple $R$ of .41 (Burkhart \& Stanton, 1985).

It would appear, from the information provided by skelton and others, that certain populations of women may be more vulnerable towards victimization than others. It also seems a woman's vulnerability increases as her exposure to dating partners increases.

Some evidence that suggests less assertive styles of communication in both general and sexual situations may be important to consider when looking at possible factors that may contribute to the victimization of a woman (Burkhart \& Stanton, 1985).

Kanin (1967), in addition to looking at characteristics of victims, began to investigate the characteristics of offenders. She surveyed 341 college males, and focused on the aggression that takes place in many courtship relationships. She found that 25.58 reported at least one sexually-aggressive incident since entering college. Incidents ranged from removing a woman's clothing against her wishes to fondling her breast or genitals after being explicitly told not to. Sex against the wishes of a partner, that is rape, was the most aggressive incident. One of the more significant findings was that the sexually aggressive male has not only had much more sexual experience than his 
non-aggressive peer, but that he also persistently looked for new sexual involvements. Kanin attributed this, in part, to the sexually aggressive males' peer group emphasis on sexual conquest. Two other important findings were reported: (1) sexually-aggressive males were much more likely to use maliciously seductive maneuvers than counterparta; and (2) despite greater sexual experience, these men tended to be more dissatisfied with their sexual activities than other non-aggressive peers.

Rapport and Burkhart did a study in 1984 which included 201 undergraduate male students. Their battery of measures were selected to reflect "conceptually relevant dimensions of coercive sexuality" (Burkhart \& Stanton, 1985, p. 17). Their measures included: Responsibility, Socialization and Empathy scales from the California Psychological Inventory, (2) Burt's (1980) scales which included Own sex Role Satigfaction, Sex Role Stereotyping, Adversarial Sexual Beliefs, Sexual Conversation, and Acceptance of Interpersonal Violence, (3) Attitudes Toward women Scale, (4) Endorsement of Force Scale, a scale introduced for the purpose of assessing the degree to which individuals endorse the use of force to obtain sexual acts, and (5) the coercive sexuality scale, a measure developed to define a continuum of coercive sexual behaviors (Burkhart \& Stanton, 1985). Analysis of the data revealed that the Coercive sexuality scale significantly helped identify men who were more likely to be aggressive as a way of obtaining sexual relations. Burkhart \& stanton also found that such variables as Adversarial sexual Beliefs, Acceptance of Interpersonal Violence, and The Endorsement of Force scale, provided information suggesting that men who coerce women into sexual relations may be identified by their scores on such measures. 


\section{Efforts to Educate}

The research thus far directs its attention to two trends that continue to persist in our everyday lives. First, men involved in aggressive relationships function in a strong belief system which reinforces the rape myths of our society. They are more often than not characterized by interpersonal irresponsibility, hostility, and a deficit in basic socialization skills. Second, while women who are involved in sexually aggressive incidents are not that easily predicted, research does show that personality and attitudinal characteristics are correlated with being victimized (Burkhart \& Stanton, 1985).

Trends reflected in the work done by Burkhart and Rapport (1984), Brownmiller (1975), Clark and Lewis (1977), and Weis and Borges (1973), focus attention on the rape culture and myths that are ever present in our society. "The rape culture is distinguished by beliefs, attitudes, and social patterns which legitimize and support forms of sexual aggression against women as a way of maintaining the inequitable distribution of power in our society" (Burkhart stanton, 1985, p.16). The work of Koss (1987) as well as Adans, Fay, and Loreen-Martin (1985) suggests that adolescents are characterized by the same beliefs and attitudes which are prevalent in a rape culture.

Given the existence of this pattern of attitudes and behaviors in adolescents, how do we identify ways of addressing these beliefs? For example, how do we go about educating students that when a woman says no she means no? Moreover, how do we teach that each of us has to take responsibility for clear communication in relationships and should show mutual respect for another's feelings and/or wishes?

Within the educational framework there have existed for many years Health Education classes at the high school level. In these classes. Drug Education, sex Education, and, more recently, AIDS Education are addressed. In reviewing only a small amount of the vast literature on the area of sex education, much information was found that addressed the 
morality of young people who choose to have sex but little information was directed at educating young adults in the area of responsible dating and/or expectations in dating relationships. Little focus is given to educating students in communication and listening skills or in the importance of listening to themselves and taking cues from what their bodies and/or minds are telling them (Bell, 1980).

saying no is difficult for many teenagers. We ask and expect them to say no to alcohol, drugs, and sex. Yet, many teens report having a very difficult time saying as well as hearing no. Bell (1980), in her book, Changing Bodies, Changing Lives, addregses the difficulty that teenagers encounter when trying to set limits around sex and intimacy. One young woman reporta that "When I tell a guy that he can touch my breasts but not my vagina because that's my limit right now, often he'll act like I was talking about the weather or something. He just keeps on going as if I didn't mean what I said" (Bell, 1980). In response to this young woman's statement, her boyfriend responds, "It's like a game. My friends told me that when a girls says no she doesn't really mean it. So, if a girl tells me quietly to stop, and doesn't yell loud about it or hit me over the head with it, I'm not supposed to listen" (Bell, 1980). From this dialogue it's clear that we need to help young men and women set limits around sex and intimacy.

If we are to help adolescents with responsible dating we need programs that have been demonstrated to effectively teach information, and provide skills for communicating, listening, and setting limits. One such effort with a health education class could be a 50-minute workshop combining information and skills acquisition.

\section{Justification for the Intervention}

There are numerous possibilities for providing information and skills acquisition regarding acquaintance rape. Any program that attempts to help young men and women set limits around sex and intimacy 
needs to address the relationship between attitudes and the incidence of acquaintance rape. This section will review educational programs regarding responsible dating and similar topics which have had some success in changing attitudes.

Responsible Dating. In studies on attitudes towards rape, gignificant differences were demonstrated between men and women. Women were found to have much harsher and more upsetting views toward rape than were men (Krulewitz, 1982). Men often accepted rape as being motivated by a desire for sex and did not look upon forced sex with an acquaintance as a rape (Barnett \& Field, 1977). Furthermore, men appeared to judge a woman's resistance as a determining factor for judging whether a rape had occurred (Briere \& Malmuth, 1983). This was also true for the situations in which the rape took place. Men in general were less likely to interpret a forced sexual experience as a rape in any situation. Women were more likely to interpret a situation as a rape if a date was a "pick-up" as opposed to a formal date where the man paid. In cases where the woman was treated by the man, women often did not view forced sex as rape (Jenkins \& Dambrot, 1987).

Rape Myth Acceptance, as described by Burt (1980), has been shown to change when students are exposed to preventive programs aimed at dispelling these myths. Donnerstein and Berkowitz (1981) reported that if students were debriefed following the viewing of pornographic material, they were less likely to accept rape myths than students in a control group who viewed non-pornographic material and were not debriefed. Donnerstein and Berkowitz (1981) also reported that when students were asked to listen to an audio tape which talked each of them through imagining they were committing a rape, their awareness of rape as a social problem increased. Twenty-one percent also reported an increase in awareness of their own aggression.

Bordon, Karr and Caldwell-Colbert (1988) conducted a study using 100 participants. Students were requested to complete two 
questionnaires, the Rape Empathy scale and the Attitudes Toward Rape Scale, both pre- and post-test. The treatment group received a $45-$ minute workshop aimed at educating students in the area of rape and prevention strategies. This study found a significant gender difference in attitudes toward rape and rape empathy, lending further support for the same results found in other studies conducted by Burt (1980) and Koss, Gidycz, and Wisniewski (1987).

Other Prevention Programs. There have been numerous studies done in the evaluation of drug education/prevention programs. In a review by Schaps, Churgin, Palley, Takata and cohen (1980), 35 drug prevention programs were evaluated. of the programs evaluated, 14 were purely informal and the remaining 21 used more creative techniques including affective, peer-oriented, and other approaches. The purpose of these programs was to educate students about drug abuse as well as to change their attitudes toward drugs.

of the evaluation studies conducted using self-reported drug use, four of the seven studies using information only to educate students showed "no effect." of those programs that used a combination of information and peer education the results showed similarly "no effect." However, those programs that included affective components showed a substantial reduction in self-reported drug use as well as in attitudes toward drugs and drug use.

Life skills Training is another program that was developed to prevent substance abuse and was implemented in both high schools and junior high schools (zins, Conyne \& Ponti, 1988). This program focused on four major areas: knowledge of both the physical and psychological effects of substance abuse, decision-making and critical thinking, acknowledgement of peer presgure and stressors surrounding substance abuse, and social skills training. Botvin and Dusenbury (1987), in reviewing the evaluation studies of the Life skills Training program found the following: 1) improved knowledge of the effects of substance 
abuse, 2) improved attitudes towards resisting substances and peer pressure to use substanceg, and 3) an actual reduction in substance abuse.

\section{Conclusion}

The results of these studies, when examined together, suggest that programs which include an affective component can both increase the acquisition of information and facilitate change. Furthermore, these studies suggest that gender differences exist in the acquisition of knowledge and change of attitude about stranger and acquaintance rape. The present study is designed to assess the questions: Whether Great Expectations, a 50-minute workshop which includes an affective component, can increase an individual's knowledge of rape and (2) Whether Great Expectations can change attitudes toward acquaintance rape.

In addition, this study will look at whether gender differences exist in the acquigition of information and change of attitudes about rape.

The following three hypotheses follow from the above questions:

Hypotheris 1. A 50-minute workshop with an affective component can increase knowledge about acquaintance rape.

Hypothesis 2. A 50-minute workshop with an affective component can change attitudes towards stranger rape and acquaintance rape.

Bypothesis 3. Before a 50-minute workshop, males will have greater acceptance of rape myths and knowledge. After the workshop, men will have gained less knowledge and will change their attitudes toward rape myths less than females. 
CHAPTER II

Method

\section{Subjects}

The sample of subjects consisted of 150 high school seniors. Seventy-five were in the control group and 75 the treatment group. The control group consisted of 35 males and 40 females. The treatment group consisted of 29 males and 45 females. Of 150 seniors, 24.78 were 16 years of age and $69.3 \%$ were 17 (Table 1 ).

\section{Table 1}

Age at Time of Study

\begin{tabular}{cc}
\hline Age & Percentage \\
\hline 13 & .78 \\
15 & .78 \\
16 & 24.78 \\
17 & 69.38 \\
18 & 4.78 \\
\hline
\end{tabular}

Ethnic background showed a majority of the students to white, with 2 studentg who were black, and 3 who were himpanic. The majority of the students were Catholic (538), with 17.38 being Protestant, and $2.7 \%$ being Jewish. The majority of the students' parents had a college education, with some having graduate degrees (Table 2 ).

Table 2

Parent'g Education

High School

$32.7 \%$

Fathers

Mothers
College

43.38

40.08
Masters/Doctorate

$22.7 \%$

18.08 
The treatment group was made up of all those high school seniors taking health education classeg the first cycle of the school year. The control group consisted of gtudents who participated in an alternative class and who will take health education during a later cycle in the year. All high school seniors are required to take this class. The high school participating in this study is located in the northeastern part of the United States and is predominantly white, middle to upper middle class.

\section{Instruments}

Instruments selected for this gtudy assessed the following areas: family background and other demographic information, attitudes as they relate to rape myth beliefg and students' knowledge of acquaintance rape.

Demographics and Personal Higtory. A quegtionnaire (See Appendix A) looked at many areas of a student's life including the following: age, sex, religion, parents education, number of siblings and their sex, and future plans for education. Students were asked at what age they started dating, their number of dating relationships and whether the majority of these relationships have been positive versus negative ones.

Attitude Scale I: Rape Myth Acceptance Scale: The Rape Myth Acceptance Scale (See Appendix B), developed by Martha R. Burt (Burt, 1980), consists of 15 items on which each individual is asked to rate their acceptance of certain rape myths on a 7-point Likert-type scale. The ratings obtained on this scale assessed students' acceptance of rape myths. Each statement is rated from strongly agree to strongly disagree. The ratings are then summed to obtain a single rape myth score. On this particular scale, the higher the score the lower the acceptance of rape myth, and the lower the score, the higher the indication of rape myth acceptance. 
Paychometric work done on the initial item pool reduced the number of items from 44 to 15 . The responses for all 44 items were carefully examined and those items measuring only one attitude were subjected to an item analyeis (Burt, 1980). Reliability, of the 15 items as indicated by Cronbach's alpha is estimated at .875 (N $=598$ using college students). In a study conducted by Jenkins and Dambrot (1987) estimates of internal consistency for the Rape Myth Acceptance Scale were .73 alpha and .75 spearman-Brown split half for females, and .76 alpha and .76 spearman-Brown split half for males.

The relationship of geveral predictive variables to the final items were also examined and how these variables related to the rape myth scale was validated in a structural model analysis. The predictive variables that were used in this work dealt with: Background (age, education, and occupation), Personality (own sex role satigfaction, romantic gelf-image and self-esteem), Experience (experience with intrafamilial violence, victim of a completed sexual assault, experience of an attempted sexual assault, number of sexual assault victims known and exposure to the media's treatments of sexual agsault) and Attitude (sexrole stereotyping, sexual conservatism, advergarial sexual beliefs and acceptance of interpersonal violence).

The results of this analysis showed that rape myth acceptance is strongly related to adversarial sexual beliefs and acceptance of interpersonal violence; with the strongest predictor of rape myth acceptance being acceptance of interpersonal violence.

Attitude Scale II: Scenarios: Jenkins and Dambrot (1987) used a procedure that was also used in the present gtudy as another index of attitudes. Three different scenarios (See Appendix C) are used describing an occurrence of forced intercourse. The only difference across the three original scenarios are the terms of the dating situation. However, after doing an initial pilot of thig instrument with approximately 125 seniors it was felt that the names should also be 
changed. This was felt necessary in order to do away with any questions as to why the same girl would subject herself to repeated incidents of forced sex. In the original form, the same names were used in all the situations. While still using the situationg designed by Jenking and Dambrot (1987), names were changed so that students could more objectively judge the situations.

An example of a scenario is as follows: "Josh asked Amy to a concert and bought both tickets for $\$ 24.00$. Josh drove Amy to and from the concert. On the way home he used physical force to obtain gex." Following reading these situations, each student is asked to rate on a Likert type scale the following: 1. Amy is responsible for Josh's behavior; 2. Josh behaved in a violent way towarda Amy; 3 . Amy wanted to have sex (Jenking \& Dambrot, 1987). The scale rangeg from 1 gtrongly agree to 7 = strongly disagree, with a maximum score of 21 for each scenario.

The study conducted by Jenking and Dambrot found a significant relationship between Burt's Rape Myth scale and the Scenarios. Using a median split to classify $\mathrm{Ss}$ into high and low agreement with rape myths ANOVAS were performed, and it was found that men who had a greater agreement with rape myths were less likely to agree that a rape had occurred in the scenario and more likely to blame the victim for what had occurred, Women appeared to take into consideration, more strongly than men, the particular gituation that the woman was in as an index of judging whether they would consider the woman as having been raped. An example of this is that women were more likely to judge a woman as being raped if it was a pick-up situation than a situation where the man paid for the date and then forced her to have sex. That is, women were less likely to perceive the latter as a rape (Jenkins a Dambrot, 1987). Although there is evidence of face validity with the use of this scale, there is limited evidence of construct validity (Jenking \& Dambrot, 1987). 
Knowledge scale. The final instrument used in this study is a knowledge based, multiple choice test (See Appendix D). The purpose of this tegt was to find out how well-informed students were in such areas as: knowing what the definition of rape is; knowing what informed consent means; understanding what the different forms of communication are. This teat included 13 multiple-choice questions.

There has been a significant amount of preliminary work conducted on these questions. The initial work was conducted by a group of six paychologists and four doctoral students in psychology. They were presented with the full workshop and directed to come up with questiong that were directed to the content of the workshop and that could be clearly understood by high school students. Approximately 200 questions were developed and then analyzed by the team developing them. Duplicate questiong and those questions that were felt to be to ambiguous were immediately discarded. A final list of 50 questions was developed. These questions were then administered to over 300 entering college students and an item analysis was conducted. Questions that were too easy were eliminated and those that were too hard, or perhaps, too confusing were reworked. Questions that displayed a relatively good distribution of scores were retained. The questions were then administered to approximately 200 students entering college and after further analyois and consultation with experta in the area of both adolescent development and acquaintance rape, 25 questions were retained. For the purpose of this study, the 13 items with the best paychometric properties were used. This was primarily due to the amount of time being allotted for atudents to fill out all the forms being asked of them.

The present study will allow for further work to be done on the scale in relation to both their reliability and validity. 


\section{Procedure}

The Institutional Review Board of the University of Rhode Island exempted this proposal, as it was judged to be a classroom evaluation of curriculum as opposed to an independent research project.

All students who participated in the study were administered a pre-test consisting of demographics, Rape Myths Scale, Scenarios, and knowledge scales one week before the workshop took place. Students were administered these by their regular classroom teachers with instructions to simply read and fill out as best as they could the forms they received. Teacherg were advised not to clarify any questions for the students in that they might sway their responses. Students were told that this is not a test and that they would not be marked on them. All students that were enrolled in the health education classes for cycle one participated in the workshop. This took place in the health class and was introduced as a part of the health teacher's overall curriculum. The workshop was led by both a male and female who had not only developed the workshop but had also administered it to over 5,000 entering college students. The workshop lasted approximately 50 minutes, and was given to six sessions of students on one day. The control group did not participate in the workshop but would be participating in Health Education classes during the following school cycle at which time they would be offered the workshop.

The post-test, consibting of the Rape Myths, Scenarios and Knowledge scales, was administered exactly one week following the workshop presentation. Classroom teachers administered the post-test with similar instructions as reviewed with the pre-test.

\section{Workshop}

Great Expectations (See Appendix E) is a 50-minute workshop aimed at educating high school and entering college students around expectations in dating relationships as well as on the importance 
communication plays in the acknowledgement of expectations. The workshop was run by both a male and female leader and was presented to a mixed sex group.

The workshop is broken up into three main parts not including the introduction to the material and the summary. The introduction is used to introduce the leaders and to give an overview of what will be covered in the workshop. Likewise, the summary is used to again review what was covered in the workshop and to give students a list of resources if they should need them.

In the first section of the workshop, the students are broken up into "same sex" groups led by the leader of that sex. During this period, which lasts approximately 5 to 10 minutes, students are asked to brainstorm and generate lists of expectationg regarding dating relationships. An example of this is as follows: the men are asked to generate two lists. First: What do men say that men want out of dating relationshipg? Second: What do men say that women want out of dating relationships?

Once both groups have generated their lists, they are asked to return to the large group, at which time the leaders put all the expectations on neweprint. It is during this section that the bulk of the material the workshop offers is covered and discussed. This is followed by the last section where scenarios are read to the whole group and students are asked to discuss their feelings about each of the situations presented.

This workshop is fagt moving and it is crucial that students participate in discussion and are given the opportunity to explore expectations and begin to dispel myths. 
CHAPTER 3

Results

\section{Summary Data}

Five dependent measures were obtained: Knowledge, rape myth acceptance, scenario 1 , scenario 2, and scenario 3. Means and standard deviations on pretest and post-test scores were calculated for each of the five measures by group (experimental versus control) as well as by sex (male versus female). The results of these calculations can be found in Table 3 .

Table 3

Mears and Standard Deviations of Pre- and Post-test of Knowledge, Rape Myth Acceptance, and Three Scenarios, Scores by Group and sex

Know. Myth scen 1 scen II scen. III

\section{Hales}

$\begin{array}{rlccccc}\text { Exper } & \text { Pre } & 8.52 & 83.10 & 13.24 & 13.41 & 13.61 \\ (\mathrm{~N}=29) & \text { SD } & (2.41) & (12.84) & (1.83) & (1.64) & (2.11) \\ & \begin{array}{l}\text { Pogt } \\ \text { SD }\end{array} & 10.31 & 83.35 & 12.90 & 12.52 & 13.31 \\ & (2.83) & (13.02) & (2.90) & (2.99) & (2.51) \\ \text { Cont. } & \text { Pre. } & 8.51 & 84.40 & 13.34 & 12.94 & 13.31 \\ (\mathrm{~N}=40) & \text { SD } & (2.82) & (7.91) & (1.80) & (2.21) & (2.21) \\ & \text { Post } & 10.81 & 86.94 & 13.51 & 13.31 & 13.22 \\ & \text { SD } & (2.55) & (12.47) & (1.50) & (1.81) & (1.91)\end{array}$

\section{Femaleg}

\begin{tabular}{|c|c|c|c|c|c|c|}
\hline \multirow[t]{2}{*}{$\begin{array}{l}\text { Exper. } \\
(N=46)\end{array}$} & $\begin{array}{l}\text { Pre } \\
\text { SD }\end{array}$ & $\begin{array}{c}9.34 \\
(2.41)\end{array}$ & $\begin{array}{c}86.31 \\
(11.50)\end{array}$ & $\begin{array}{l}13.94 \\
(2.50)\end{array}$ & $\begin{array}{l}13.40 \\
(2.60)\end{array}$ & $\begin{array}{l}14.11 \\
(1.95)\end{array}$ \\
\hline & $\begin{array}{l}\text { Post } \\
\text { SD }\end{array}$ & $\begin{array}{l}12.11 \\
(1.91)\end{array}$ & $\begin{array}{c}89.83 \\
(11.21)\end{array}$ & $\begin{array}{l}13.51 \\
(3.11)\end{array}$ & $\begin{array}{l}13.13 \\
(3.21)\end{array}$ & $\begin{array}{l}13.54 \\
(2.91)\end{array}$ \\
\hline \multirow[t]{2}{*}{$\begin{array}{l}\text { Cont } \\
(N=40)\end{array}$} & $\begin{array}{l}\text { Pre } \\
\text { SD }\end{array}$ & $\begin{array}{c}9.90 \\
(2.11)\end{array}$ & $\begin{array}{c}85.31 \\
(14.81)\end{array}$ & $\begin{array}{l}14.20 \\
(1.42)\end{array}$ & $\begin{array}{l}13.81 \\
(1.92)\end{array}$ & $\begin{array}{l}13.91 \\
(1.71)\end{array}$ \\
\hline & $\begin{array}{l}\text { Pogt } \\
\text { SD }\end{array}$ & $\begin{array}{l}12.11 \\
(1.64)\end{array}$ & $\begin{array}{c}87.53 \\
(16.43)\end{array}$ & $\begin{array}{l}13.90 \\
(1.34)\end{array}$ & $\begin{array}{l}13.70 \\
(1.91)\end{array}$ & $\begin{array}{l}13.73 \\
(1.71)\end{array}$ \\
\hline
\end{tabular}


Questions on dating behaviors were summarized using categorical frequencies (See Tables $4,5 \& 6$ ).

Table 4

Frequency of Dating $(N=150)$

Frequency Dated Number Responding

1 = Never 14

2 = Less than $1 /$ month 27

$3=1$ per month 12

$4=2$ to 3 per month 35

$5=1$ per week 24

$6=2$ times per week 18

7 = More than 2 times/week 18

Table 5

Number of Dates in the Past Six Months

Number of Dates in

Past Six Months

Number Responding

$\begin{array}{cr}1 & 70 \\ 2-3 & 49 \\ 4-5 & 20 \\ 6-7 & 5 \\ 8-9 & 1 \\ 10-11 & 0 \\ 12-13 & 2\end{array}$

Table 6

Age at the Time of First Date

\begin{tabular}{lc}
\hline Age & Number Responding \\
\hline 10 & 2 \\
11 & 1 \\
12 & 17 \\
13 & 22 \\
14 & 38 \\
15 & 40 \\
17 & 26 \\
\end{tabular}


Two separate MANOVAs of rape myth acceptance and knowledge, and scenarios 1, 2 and 3 were calculated. Because the scenarios are experimental in nature, and the reliability and validity are so uncertain, geparate MANOVAg were utilized.

\section{Preliminary Analyses}

According to the literature review it was expected that there would be initial differences in the scores for men and woman, however, no differences were expected between the experimental and control groups. In order to test for these differences, two, $2 \times 2$ MANOVAs were run on pretest scores only (SPSS-X Release 3.0 for VAX/UNIX). The first of these utilized rape myth and knowledge as the dependent variables, with group (experimental versus control) and sex (male versug female) as the independent variables. Testg for homogeneity of variance were nonsignificant using Cochran's $Q$ : Myths $=.375$, Knowledge $=.339, \mathrm{P} \leq$ .01. A significant main effect for gex was found using Wilk's approximation to $F ; F(2,145)=3.88, p<.02$. Separate univariate ANOVA' $\theta$ were calculated resulting in a significant sex effect for Knowledge, $F(1,146)=7.5, \mathrm{p}<.007$, but not for myths, $F(1,146)=.039$, $p<.842$. The $F$ values and asgociated probabilities for all comparisons can be found in Table 7 .

\section{Table 7}

Summary Table of $2 \times 2$ MANOVA of Rape Myth Acceptance and Knowledge, and Univariate Follow-up for Significant Main Effecta

\begin{tabular}{llll}
\hline Source & df & $\mathbf{F}$ & $\mathbf{P}$ \\
\hline Group & 2,145 & .23 & .79 \\
Sex & 2,145 & 3.88 & $.0233^{\star}$ \\
$\quad$ Krths & 1,146 & 7.5 & .842 \\
Krowledge & 1,146 & 1.71 & $.007^{\star}$ \\
Group \& Sex & 2,145 & & .18 \\
\hline
\end{tabular}


The second $2 \times 2$ ManOVA utilized scenario 1 , scenario 2 , and scenario 3 pretest scores as the dependent measures, with group (experimental versus control) and sex (male versus female) as the independent meagures. Test for homogeneity of variance was nongignificant using Cochran's $Q$ : Scenario $1=.401$, scenario $2=.361$, Scenario $3=.314, \mathrm{p} \leq .01$. No significant differences were noted for any of the comparisons. The F valueg and associated probabilities for all comparisons can be found in Table 8 .

Table 8

Summary Table of $2 \times 2$ MANOVA of Pretest scenarios scores

\begin{tabular}{lccc}
\hline Source & df & $\mathbf{F}$ & $\mathbf{p}$ \\
\hline Group & 3,144 & .701 & .553 \\
Sex & 3,144 & 1.92 & .128 \\
Group \& Sex & 3,144 & .69 & .556
\end{tabular}

It can be concluded from the above analyges that females ocored significantly higher than males on pretest knowledge scores as, predicted in hypothesis 2. All other pretegt differences were nonsignificant, thus concluding that the initial control and experimental groups were equivalent.

\section{Effects of the Treatment}

Two 2 (treatment versus control) $\times 2$ (men versus women) $\times 2$ (pretest versus post-test) three factor MANOVAs, with the third factor as a repeated measure were utilized for the experimental design. The first MANOVA analyzed two dependent variables, knowledge and rape myth. Tests for homogeneity of variance were nonsignificant using Cochran's $Q$ : Myths $=.130$, Knowledge $=.339, \mathrm{p} \leq .01$. Using Wilk's approximation to 
the $F$ gtatiatic there was a significant main effect for sex, $F(2,145)=$ 7.17, $p<.001$. Univariate analyses further clarified this finding with knowledge being significant, $F(1,146)=13.87, \mathrm{p}<.01$, indicating that females knew more on the knowledge based measures than did males. The mean score for males was 9.53 and 10.83 for females. Myths were nonsignificant, $F(1,146)=1.08, p<.30$.

Furthermore, there was also a significant main effect for pretest/post-test, using the wilk's approximation to the $F, F(2,145)=$ 112.003, $p<.001$. Follow-up univariate analysis reinforced the pretest/post-test finding for knowledge $F(1,146)=216.72, p<.01$, but not for myths, $F(1,146)=3.50, p<.063$, indicating that all groups improved in knowledge over time (Pretest mean $=9.12$; post-test = 11.43). Completed analysis of this MANOva shows that all other main effects as well as interaction effects were not significant at the .05 level (see Table 9).

\section{Table 9}

Summary Table for $2 \times 2 \times 2$ MANOVA of Knowledge and kape Myth Acceptance Scores and Univariate Follow-up tests for Significant Main Effects

\begin{tabular}{|c|c|c|c|}
\hline Source & df & $\mathbf{F}$ & $\mathbf{p}$ \\
\hline Group (G) & 2,145 & .22 & .80 \\
\hline $\begin{array}{l}\text { Sex (S) } \\
\text { Hythe } \\
\text { Knowledge }\end{array}$ & $\begin{array}{l}2,145 \\
1,146 \\
1,146\end{array}$ & $\begin{array}{r}7.17 \\
1.08 \\
13.87\end{array}$ & $\begin{array}{l}.001 * \star \star \\
.30 \\
.01 * \hbar\end{array}$ \\
\hline $\begin{array}{l}\text { Pretest/ } \\
\text { Post-test (P/P) } \\
\text { Myths } \\
\text { Knowledge }\end{array}$ & $\begin{array}{l}2,145 \\
1,146 \\
1,146\end{array}$ & $\begin{array}{c}112.00 \\
3.51 \\
216.7\end{array}$ & $\begin{array}{l}.001 * \star * \\
.063 \\
.001 * * *\end{array}$ \\
\hline G $\mathbf{X} \mathbf{S}$ & 2,145 & 1.58 & .21 \\
\hline$G \times P / P$ & 2,145 & .017 & .98 \\
\hline$S \times P / P$ & 2,145 & 2.58 & .07 \\
\hline$G \times S \times P / P$ & 2,145 & 1.34 & .26 \\
\hline
\end{tabular}


A second 2 (treatment versus control) $x 2$ (men versus women) $x$ 2 (pretest versus post-test) three factor MANOVA with the third factor as a repeated measure was utilized to analyze scores on the three dependent variables: scenario 1 , scenario 2 , and scenario 3. Tests for homogeneity of variance were nonsignificant using Cochran's Q: Scenario $1=.133$, Scenario $2=.143$, Scenario $3=.144$, p $\leq .01$. Using Wilk's approximation to the F statigtic, there were no significant main effects or interaction effects. However, the group main effect approached significance $(F=2.62), d f=3 / 144 . p=.053$, suggesting a trend toward lower scores in the combined treatment groups across scenarios. The complete results of these analyses can be found in Table 10.

Table 10

Summary Table for $2 \times 2 \times 2$ MANova of Scenario 1 , Scenario 2 , and Scenario 3

\begin{tabular}{lccc}
\hline Source & df & $\mathbf{F}$ & P \\
\hline Group (G) & 3,144 & 2.62 & .05 \\
Sex (S) & 3,144 & 1.48 & .22 \\
Pretegt/ & & .91 & .44 \\
Post-tegt (P/P) & 3,144 & .24 & .89 \\
G S S & 3,144 & 1.40 & .25 \\
G X P/P & 3,144 & .40 & .75 \\
$\mathbf{S} \times \mathbf{P} / \mathbf{P}$ & 3,144 & 1.24 & .28 \\
$\mathbf{G} \times \mathbf{S} \times \mathbf{P} / \mathbf{P}$ & 3,144 & & \\
\hline
\end{tabular}

Reliability and Intercorrelations of Measureg

Internal consistency estimates as well as tegt-retest reliability estimates were obtained on rape myth acceptance and knowledge scores. Test-retest estimates were also obtained on the three scenariog.

Internal consistency estimates were calculated for 143 subjects on both pretest and post-test scores for the rape myth acceptance scale. 
The alpha estimates equaled .71 for the pretest and .77 for the posttest scores. Test-retest reliability estimates were calculated for the rape myth acceptance scale using only the control group ( $N=75$ ) pre- and post-test scores. Reliability was estimated at .69 . Burt (1980) in her original work on this scale reported an estimated alpha of .85 ( $N=598$ ); Jenkins and Dambrot (1987), reported an estimated .73 alpha and a splithalf reliability of .75 for females $(N=318$ ), and .76 alpha and .76 split-half for males $(N=326)$. It would appear that the findings in the present study are consistent with those previously reported.

similar estimates were calculated for knowledge scores. The numbers of subjects both pre and post-test were 150. The alpha estimate on the pretest scores was .65 and on the post-test score .61 . The original alpha calculated for this scale was estimated at .91, using a total $\mathrm{N}=787$ and at the time the number of questions was 50 . It is possible that the reduction in the number of questions could account for the lower alpha reported in the present study.

In order to calculate test-retest reliability, the pretest and post-test knowledge scores were used for the control group only (N=75), administered within a three week interval. The results of this was an estimated reliability of .75 . It would appear that reducing the number of questions on the knowledge scale led to somewhat reduced alphas, suggesting some heterogeneity among items, yet test-retest reliability estimates indicate relative consistency over time.

It appears that both the knowledge questions and the rape myth scale are fairly reliable ingtruments and that the results found in this study are consistent with those reported in past studies.

The intercorrelations for rape myth acceptance, knowledge scales, and three scenarios are reported in Table 11 . These are reported in all combinations for both pretest and post-test scores. All relationships reported are significant at the .01 level or less. The correlation between knowledge and rape myths on pretest scores $=.26$, while on the 
post-test the correlation $=.47$. These correlations suggest that in fact there is a significant amount of relatedness between knowledge of dating behaviors and rape myth acceptance. In post-test correlations, the interrelations were even stronger than pretest, suggesting that possibly, the more exposure an individual has to information addressing these issues the stronger the interrelations will likely become.

Table 11

Pre/Post-test Correlations and Intercorrelations of Knowledge, Rape Myth Acceptance, and Scenario 1 , Scenario 2 , and Scenario $3 .(\mathrm{N}=150)$.

\begin{tabular}{|c|c|c|c|c|c|c|c|c|c|}
\hline & $\mathrm{K}$ & PK & $\mathbf{M}$ & PM & $S I$ & PSI & SII & PSII & SIII \\
\hline $\begin{array}{l}\text { PK } \\
\text { M } \\
\text { PM } \\
\text { SI } \\
\text { PSI } \\
\text { SII } \\
\text { PSII } \\
\text { SIII } \\
\text { PSIII }\end{array}$ & $\begin{array}{l}.70^{c} \\
.26^{c} \\
.45^{c} \\
.19^{b} \\
.31^{c} \\
.22^{b} \\
.22^{b} \\
.31^{c} \\
.24^{b}\end{array}$ & $\begin{array}{l}.31^{c} \\
.47^{c} \\
.19^{b} \\
.32^{c} \\
.25^{c} \\
.43^{c} \\
.25^{c} \\
.42^{c}\end{array}$ & $\begin{array}{l}.60^{c} \\
.16^{a} \\
.16^{a} \\
.24^{c} \\
.27^{c} \\
.19^{b} \\
.23^{c}\end{array}$ & $\begin{array}{l}.22^{b} \\
.29^{c} \\
.29^{c} \\
.37^{c} \\
.22^{b} \\
.38^{c}\end{array}$ & $\begin{array}{l}.46^{\mathrm{c}} \\
.61^{\mathrm{c}} \\
.48^{\mathrm{c}} \\
.65^{\mathrm{c}} \\
.44^{\mathrm{C}}\end{array}$ & $\begin{array}{l}.47^{c} \\
.76^{c} \\
.52^{c} \\
.81^{c}\end{array}$ & $\begin{array}{l}.61^{c} \\
.69^{c} \\
.55^{c}\end{array}$ & $\begin{array}{l}.55^{c} \\
.84^{c}\end{array}$ & $.57^{c}$ \\
\hline
\end{tabular}

Interrelations of the scenarios were also calculated. In combination, this information suggests that while the scenariog are only moderately reliable instruments, there is a significant amount of relatedness between each of the three scenarios. Test-retest reliability estimates were calculated for each of the three scenariog using only the control group ( $N=75)$. Reliability was estimated at .61 for scenario 1, .69 for scenario 2, and .57 for scenario 3.

\section{Relationship Between Dating Behavior and Test Scores}

Correlations were investigated between rape myth acceptance and knowledge with three areas of dating behaviors obtained from the 
demographic questions: the age of first date, frequency of dating and the number of different people dated over the past six months. The results of these correlations can be seen in Table 12 . The only significant correlation at the .05 level was the relationship between age at the time of a firgt date and the knowledge questions. This suggests that the later individuals enter into dating relationships the greater their knowledge of dating behaviors are likely to be.

Table 12

Pre- and Post-test Correlations of Rape Myth Acceptance and Knowledge with Dating Frequency, Number of Different Dates in the Last Six Months, and Age at the Time of Firgt Date

\begin{tabular}{|c|c|c|c|c|}
\hline & Myth & Post/Myth & Knowledge & Post/Knowledge \\
\hline $\begin{array}{l}\text { Dating } \\
\text { Frequency }\end{array}$ & $p=.06$ & 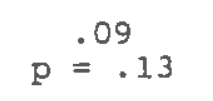 & 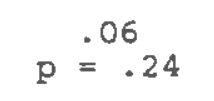 & $\stackrel{.12}{=} .08$ \\
\hline $\begin{array}{l}\text { \# of Different } \\
\text { Dates in the } \\
\text { past } 6 \text { mo. }\end{array}$ & $p^{-.07}=.19$ & 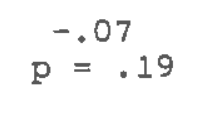 & $\begin{array}{l}-.09 \\
p=.14\end{array}$ & $p^{-.11}=.09$ \\
\hline $\begin{array}{l}\text { Age at the } \\
\text { Time of lst } \\
\text { Date }\end{array}$ & 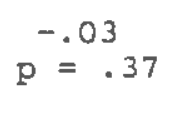 & $\mathrm{p} \stackrel{.04}{=} .27$ & $p=.14 *$ & $p=.15 *$ \\
\hline
\end{tabular}


CHAPTER 4

Discuseion

Consistent with the literature (Burt, 1980; Field, 1978; Check \& Malamuth, 1981, and Jenking and Dambrot, 1987), as well as with hypothesis 3 of this study, females knew more than males on knowledge based questions, suggesting females have a greater understanding of dating behaviors than do males. Brownmiller (1975), Koss and Oros (1982), and Burt (1980) all suggest that the above findings are based on a society that reinforces females for being the one's in a relationship who are responsible, empathetic and knowledgeable in the area of relationships.

While females were significantly more knowledgeable than males, another important finding emerged. All groups, experimental, control, males and female,s improved in their level of knowledge. This suggests that while women have more knowledge of dating relationships, both men and women are capable of changing over time. There are several possible explanations for this reault.

It is possible that spread of effects could have contributed to the gain in knowledge that was found in the control group over the three week interval. All the students involved in the workshop as well as in the control group were seniors from a relatively small high school. It is not unlikely that, with their excitement and enthusiasm over having had the workshop, those seniors in the treatment group continued discussing the workshop with friends and other students throughout the day and week following the workshop. These discussions could have impacted on the gain in knowledge that was found in the control group. It is possible that a comparison group from another high school could help control for the spread of effects that may have impacted on the present study.

Another possible explanation for the above resultg is related to the time at which the post-tests were administered. Post-test data were 
collected one week after the treatment took place. It is likely that in the course of the week following the treatment, the effects dissipated, thus showing no significant change between the experimental and control groups. Had the post-test been administered immediately following the treatment, the results may have been different. This is also another way to reduce the contamination of regults that could be caused by spread of effects.

Given the enthusiasm of participants in this and previous presentations of the workshop, the lack of significant treatment effects was disappointing. In addition to possible dissipation of effects, possible contributors to lack of effects relate to some other internal validity issues and to the psychometric properties of the test. Harrison, Downes, \& Williams (1991) suggest that the pretests themselveg may have primary effects, thus heightening the awareness for all groups exposed to them. This could possibly account for the results of the present study which found that all groups improved over time. It's possible that had there been a control and treatment group posttest only, as in a solomon 4-group design, this effect could have been isolated.

Great Expectations was offered to high school students as a direct result of feedback from hundreds of college orientation students. Although students appeared interested and involved in the workshop during the present study, the measures used were indirect and did not give any kind of substantial information on satisfaction or dissatisfaction with the workshop, or what part of the workshop students found mogt helpful and/or informative. Direct evaluation of the workshop might have been helpful in understanding why some of the expected effects did not occur.

Bordon, Karr, and Caldwell-Colbert (1988) found that prevention programs attempting to affect attitude change were more successful if a variety of different ways of providing information were utilized. They 
recommended offering students an affective component and a knowledge (lecture) section, as well as time for students to put to practical use what has been discussed throughout the workshop. It is possible that Great Expectations, although offering information in a variety of ways, was too much in too short a period of time for students. This could in turn result in students' frustration and possible overload on the information received during the 50-minute session. It should be noted that many students at the end of each workshop would comment on their desire for additional classes on the topic leading to the conclusion that although students were interested, the 50 minutes allotted for this workshop may not have been enough to elicit the kind of response desired. Schaps, Churgin, Palley, Takata, and Cohen (1980) in their evaluation of many prevention programs dealing with drug use and abuse, reported similar recommendations.

The studies by Borden et al. (1988) and Schaps et al. (1980) suggest the importance of both primary sessions as well as booter sessions in sensitizing students to reinforcing information received in a workshop such as Great Expectations. It is possible that had primary sessions been uged, gtudents' level of awareness may have been heightened leading to more optimal learning during the workshop. Booster sessions could have added follow-up reinforcement for the students gains and with the use of both these techniques, it may have been possible to effect more changes for the students involved in the treatment group.

Another possibility may be due to the amount of knowledge and rejection of rape myths already established in this population. In her original work, Burt (1980) reported a mean score of 49.4 , for her population ranging in age from 15 to 25 . (It's important to keep in mind the lower the score the higher the acceptance of rape myths.) In this high school population, the lowest mean score was 83.10, which is significantly higher than the scoreg Burt reported. Therefore, it's 
possible that, although there was room to improve (with a possible maximum score of 140) there was something of a ceiling effect.

The scales used in this study were only moderately reliable with estimates in the mid 70's for the Knowledge and Rape Myth scaleg and in the $60^{\prime} \mathrm{g}$ for the Scenarios. With better reliability, significance might have emerged. Although this study has contributed to the reliability and validity of these instruments, further work needs to be done to refine them.

The Knowledge scale was decreased in number of original questions from 50 to 13 for the purpose of this study. The reduction in questions impacted on it's reliability, therefore, it would be important to rework the items to give us the most reliable measure with such few questions as well as to increase the length of the test.

Minimal psychometric work has been done on the scenarios prior to this study. Initial findings with reliabilities in the 60 's suggest a need for considerable refinement of these scale. Internal consistency estimates need to be calculated and the scoring system of the scenarios needs further investigation. Presently, the scenarios are scored by combining all these ratings on each scenario. Other combinations of ratings or evaluation of each rating separately might lead to more reliable and valid findings.

The main effect for treatment in the MANOVA for the scenarios approached significance. Given that the scenarios show only mediocre reliabilities, refinements of the scale seem warranted.

The significant relationship between age of individuals at the time of their first date and knowledge of dating behaviors indicates that the older individuals are at the time of their first dates, the more likely they are to understand what dating relationshipg are about. It is posaible that a third variable plays a role in the relationship between age of first date and knowledge. The high school used for this study is from an upper-middle class commuity where the majority of families are 
college educated and beyond; and are predominantly catholic. Both age of dating and knowledge of dating relationships could be related to these other variables.

The gignificant relationship between rape myth acceptance and knowledge suggestg that if individuals are knowledgeable in dating behaviors and communication styles, they are also likely to have legs acceptance of rape myths. The higher correlation on post-test scores for rape myth acceptance and knowledge should be explored further to understand how change in one parallels the other.

\section{Future Directions}

What we have seen both in the present study and in past studies dealing with educating students and changing attitudes is that the approach to delivering information is of greatest importance. Several approaches have been discussed which deal with more vivid interactive programs aimed at enhancing the students' ability to process and incorporate information obtained during a preventive program. Possible changeg to be addressed with the Great Expectations workshop in future research are as follows: 1) increasing both the length of time of the workshop for any given session as well as increasing the number of segsions used to run the workshop; 2) the possibility of using introductory sessions for primary effects and booster sessions to reinforce the effects of the program; and 3) exploring the possibility of finding, or improving on, instruments to measure the effectivenesg of change in attitudes and knowledge.

\section{Conclusions}

This study is one of the firgt of it's kind to be implemented in a high school setting. It was apparent that the students were eager to be involved in the workshop while at the same time their frugtration at the lack of time to continue discussions was equally noticeable. 
It has taken many years to find appropriate ways to educate students in the area of drug use and abuse. Taking some of what has been learned about changing attitudes in these situations, and incorporating them into a preventive program such as Great Expectations, can only help to improve the quality and effectiveness of the program.

It is clear from the feedback from studentg both in the present study and in past groups involved in Great Expectations, that there is an interest on the part of students for such a workshop. Continued work needs to be carried out in how to most effectively change attitudes toward rape myths and to increase males and females knowledge of dating relationships. This has clearly been an initial attempt to do so, but much work ig left to be done. 
References

Abbey, A. (1982). Sex differences in attributions for friendly behavior: Do males misperceive females' friendliness? Journal of Personality and Social Psychology, 42, 830-838.

Adams, C., Fay, S., \& Loreen-Martin, J. (1985). No Is Not Enough: Helping Teenagers Avoid Assault. Impact Publishers.

Barnett, N.J., \& Field, H.S. (1977). Sex differences in university students' attitudes toward rape. Journal of College student Personnel, 18, 93-96.

Bell, R. (1980). Changing Bodies, Changing Lives. New York: Random House.

Bolander \& Stodden. (Eds.). (1986). The Merriam-Webster Dictionary. Pocket Books.

Bordon, L.A., Karr, S.K., \& Caldwell-Colbert, A.T. (1988). Effects of a University Rape Prevention Program on Attitudes and Empathy Toward Rape. Journal of College Student Development, 29, 132-136.

Botvin, G.J., \& Dusenbury, L. (1987). Life skills training: A pgychoeducational approach to substance-abuse prevention. In $\mathrm{C}$. Maher \& J.E. Zins (Eds.), Psychoeducational interventions in the schools (pp. 46-65). New York: Pergamon.

Brownmiller, S. (1975). Againgt our will: Men, women, and rape. New York: Simon \& Schuster, 1975.

Burkhart, B.R., \& Stanton, A.L. (1985). Sexual aggression in acquaintance relationships. In G. Russell (Ed.)., Violence in intimate relationships. Spectrum Press.

Burt, M.R. (1980). Cultural myths and supports for rape. Journal of Personality and Social Psychology, 38, 217-230.

Campbell, P. (undated). Are we encouraging rape? Georgia state University.

Check, J.V.P., \& Malamuth, N.M. (1983). Sex role stereotyping and reactions to depictions of stranger versus acquaintance rape. Journal of Personality and Social Psychology, 45, 344-356.

Clark, L., \& Lewis, D. (1977). Rape: The price of coercive sexuality. Toronto, Canada: The Women's Press.

Donnerstein, E., \& Berkowitz, L. (1981). Victim reactions in aggresgive erotic films as a factor in violence against women. Journal of Personality and Social Psychology, 41(4), 710-724.

Ehrart, J.K., \& Sandler, B.R. (1985). Campus gang rape: Party games? Project on the Status and Education of Women, Association of American Colleges. 1818 R. St., N.E., Washington, DC 20009.

Harrison, P.J., Downes, J., \& Williams, M.D. (1991). Date and Acquaintance rape: Perceptions and attitude change otrategieg. Journal of College student Development, 32, 131-139. 
Jenkins, M.J., \& Dambrot, F.H. (187). The attribution of date rape: Observer's attitudes and sexual experiences and the dating situation. Journal of Applied Social Psychology, 17, 875-895.

Kanin, E. (1969). Selected dyadic aspects of male sex aggression. Journal of Sex Research, $\underline{5}, 12-28$.

Kanin, E.J., \& Parcell, S.R. (1977). Sexual aggression: A second look at the offended female. Archives of Sexual Behavior, 6, 67-76.

Kirkpatrick, C., Kanin, E.J. (1957). Male sex aggression on a university campus. American Sociological Review, $22,52-58$.

Klemmack, S.H., \& Klemmack, D.L. (1976). The social definition of rape. In M.J. Walker \& S.L. Brodsky (Eds.), Sexual Assault. Lexington, MA: Heath.

Korman, S.K., Leslie, G.R. (1982). The relationship of feminist ideology and data expense sharing to perception of sexual aggression in dating. The Journal of Sex Research, 18, 114-129.

Koss, M.O., Gidycz, C.A., \& Wisniewski, N. (1987). The acope of rape: Incidence and prevalence of sexual aggression and victimization in a national sample of higher education students. Journal of Congulting and Clinical Psychology, 55, 162-170.

Koss, M.O., \& Oros, C.J. (1982). The Sexual Experiences Survey: A research instrument investigating sexual aggression and victimization. Journal of Consulting and Clinical Pgychology, 50, 455-457.

Krulewitz, J.E. (1982). Sex differences in the evaluation of females and male victims' responses to asgault. Journal of Applied Social Psychology, 11, 460-474.

L'Armand, K., \& Pepitone, A. (1982). Judgements of rape: A study of victim-rapist relationship and victim sexual history. Personality and Social Psychology Bulletin, $8,134-139$.

Oros, C.J., Leonard, K., \& Koss, M.P. (1980). Factorg related to self attribution of rape by victims. Paper presented at the meeting of the American Psychological Association, Montreal, Canada.

Rapport, K., \& Burkhart, B.R. (1984). Personality and attributional characteristics of sexually coercive college males. Journal of Abnormal Psychology, 93, 216-221.

Schapg, E., Churgin, S., Palley, C.S., Takata, B., \& Cohen, A.Y. (1980). Primary prevention research: A preliminary review of program outcome studieg. The International Journal of the Addictiong, $15,657-676$.

Seligman, J., Huck, J., Joseph, N., Namuth, T., Prout, L., Robinson, T.L., \& McDaniel, A.L. (1984, April 9). The date who rapes. Newsweek, pp. 91-92.

Skelton, C.A. (1982). Situational and personological correlates of sexual victimization in college women. Unpublished doctoral disaertation, Auburn Univeraity, Alabama.

Sweet, E. (1985). Date rape: The story of an epidemic and those who deny it. Ms/Campus Times, pp. 54-85. 
Weig, K., \& Borges, s.s. (1973). Victimology and rape: the case of the legitimate victim. Issues in Criminology, $\underline{8}, 71-115$.

Zing, J.E., Conyne, R.K., \& Ponti, C.R. (1988). Primary prevention: expanding the impact of psychological services in schools. School Psychology Review, 17, 542-549. 


\section{APPENDIX A}

I would like to ask you some general background guestions.

1. Your sex: _ Male Female

2. How old are you today?

3. What is your race or ethnic background? (Check one) White _ Black_ Hispanic___, other (Specify)

4. What is your religious background? Catholic J_, Jewish ___ Protestant , other (specify)

5. Circle your father's highegt year of education completed. [High School -----] [Coliege ------] [Master's/Doctorate-----] $\begin{array}{lllllllllllllll}6-8 & 9 & 10 & 11 & 12 & 13 & 14 & 15 & 16 & 17 & 18 & 19 & 20 & 21 & 22+\end{array}$

6. Circle your mother's higheet year of education completed. [High school -----] [College --..--] [Master's/Doctorate-----]

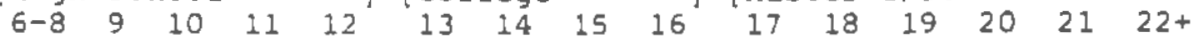

7. What type of job does your father have? (specify)

8. What type of job does your mother have? (specify)

9. Number of brothers:

10. Number of sigters:

11. How often do you date? Never Lesg than once per month About once per month About once per week More than twice per week , Two or three dates per month Twice per week

12. How many different people have you dated over the past six months? $0-1,2-3,6-5$ $12-1 \overline{3}, 14$ Or more , $8-9+10-11$

13. How old were you at the time of your first date alone with a girlfiend/boyfiend?

14. What do you plan to do next year after graduation (check one) Go to college Hork full time college Travel , Take a year off before

15. How would you describe the majority of your dating relationships: Positive, Negative, More negative than positive. More positive than negative, 


\section{APPENDIX B}

Please read each of the following statements and take a few moments to think about how you feel in response to each statement. Pleage circle the number which best describes your feelings in relation to each statement. Do not spend too much time on any one statement and if you have difficulty. please just circle you first reaction to the statement. It's important to rememiber there are no right or wrong answers.

Answers range accordingly:

Almost

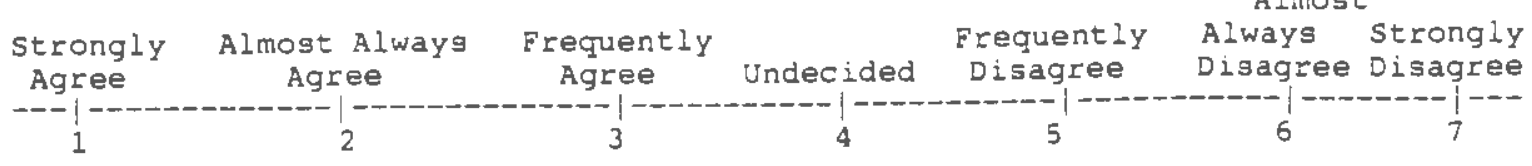

\section{statements:}

1: A woman who goes to the home or apartment of a guy on their first date implies that she is willing to have sex

2. Any female can be raped.

3. One reason that women falgely report a rape ig that they frequentiy have a need to call attention to themselves

4. Any healthy woman can guccessfully resist a rapist if she real1y wants to.

5. When womer go around braless or wearing short skirts and tight tops, they are just asking for trouble.

6. In the majority of rapes, the victim is promiscuous or has a bad reputation.

$\begin{array}{lllllll}1 & 2 & 3 & 4 & 5 & 6 & 7\end{array}$

7. If a girl engages in necking or petting and ghe lets things get out of hand, it is her own fault if her partner forces sex on her.

8. Women who get raped while hitchniking get what they deserve.

9. A woman who ig stuck-up and thinks she is too good to talk to guys on the street degerves to be taught a iesson.

10. Many women have an unconscious wigh to be raped, and may then unconsciougly set up a gituation in which they are likely to be attacked.

11. If a wornan gets drunk at a party and has gex with a man she's just met there, she should be considered "faiI game" to other guys at the party who want to have sex with her too, whether ohe wants to or not.

12. A large percentage of women who report a rape are lying because they are angry and want to get back at the guy.

13. Women who discover that they are pregnant may invent they were raped as a way to protect their reputation. 
Answerg range accordingly:

\begin{tabular}{|c|c|c|c|c|c|c|}
\hline \multirow[b]{2}{*}{$\begin{array}{l}\text { Strongly } \\
\text { Agree }\end{array}$} & \multirow[b]{2}{*}{$\begin{array}{c}\text { Almost Always } \\
\text { Agree }\end{array}$} & \multirow[b]{2}{*}{$\begin{array}{l}\text { Frequently } \\
\text { Agree }\end{array}$} & \multirow[b]{2}{*}{ Undec ded } & \multicolumn{3}{|c|}{ Almost } \\
\hline & & & & $\begin{array}{c}\text { Erequent } 1 \gamma \\
\text { Disagree }\end{array}$ & $\begin{array}{l}\text { Always } \\
\text { Disagree }\end{array}$ & $\begin{array}{l}\text { Strongly } \\
\text { Disagree }\end{array}$ \\
\hline$i$ & 2 & 3 & 4 & 5 & 6 & 7 \\
\hline
\end{tabular}

Statements:

14. A person comes to you and claims they were raped. How likely would you be to agree that they had been if the person were:
a) your best friend
b) an Indian woman
c) a neighborhood woman
d) a young boy
e) a black woman
f) a white woman

$\begin{array}{lllllll}1 & 2 & 3 & 4 & 5 & 6 & 7\end{array}$

$\begin{array}{lllllll}1 & 2 & 3 & 4 & 5 & 6 & 7\end{array}$

$\begin{array}{lllllll}1 & 2 & 3 & 4 & 5 & 6 & 7\end{array}$

$\begin{array}{lllllll}1 & 2 & 3 & 4 & 5 & 6 & 7\end{array}$

$\begin{array}{lllllll}1 & 2 & 3 & 4 & 5 & 6 & 7\end{array}$

$\begin{array}{lllllll}1 & 2 & 3 & 4 & 5 & 6 & 7\end{array}$

15. If a woman is raped by a friend it is really not rape but gome Eorm of miscommunication.

Burt, M.R. (1980). Cultural myths and supports for rape. Journal of Personality and social Psychology, 38, 217-230. 


\section{APPENDIX C}

Pleage read the following situations and take a few moments to think about how you feel in response to each specific situation. Please circie the number which best describes how you feel towards each of the situacions. It's important to remember there are no right or wrong answers.

Answers range according?

\begin{tabular}{|c|c|c|c|c|c|c|}
\hline & & & & \multicolumn{3}{|c|}{ Almost } \\
\hline Strongly & Almost Always & Erequent $1 \mathrm{y}$ & & Frequent ly & Always & Strongly \\
\hline Agree & Agree & Agree & Undec ided & Disagree & Disagre & Disagree \\
\hline
\end{tabular}

\section{situations}

1. Josh asks Amy to a concert and buys both tickets for

\$24.00. Josh drives Amy =o and from the concert.

on the way home he uses physical force to obtain sex.

Any is respongibie for Jogh's behaviors.

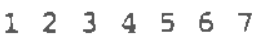

Josh behaved ir a violent way towards Any.

1234567

Any wanted to have sex.

$\begin{array}{lllllll}1 & 2 & 3 & 4 & 5 & 6 & 7\end{array}$

2. David and Al happen to see each other at a concert.

David offezs to give Ali a ride home. Ali tellg her

friends that she nas declded to drive home with David.

on the way home, David uses force to obtain sex.
Ali is responsible for David's behaviors.
$\begin{array}{llllllll}1 & 2 & 3 & 4 & 5 & 6 & 7\end{array}$
David behaved ir a violent way toward Ali.
$\begin{array}{lllllll}1 & 2 & 3 & 4 & 5 & 5 & 7\end{array}$
Ali wanted to have sex.
$\begin{array}{lllllll}1 & 2 & 3 & 4 & 5 & 6 & 7\end{array}$

3. Jeanne asks Todd to go to a concert. They each pay their own ticket, \$13.62 each. Todd driveg Jeanne to and frcm the concert. On the way home, Todd uses force to obcain sex.

Jeanne is zesponsible for Todd's behaviors. Todd behaved in a violent way toward Jeanne. Jeanne wanted to have sex.

Jenkins, M.J., \& Dambrot, F.H. (1987). The Attribution of Date Rape: Observer's Attitudes and sexual Experience and the Dating Situation, Journal of Applied Social Pgychology, 17, 875-895. 


\section{APPENDIX D}

Please answer the following question the way you feel chey should be answered.

1) As adults, it's important that we learn to:

a) Put our own needs aside to meet the needs of those around us.

b) Learn that we need to give to those around ug, and in time get our own reeds met.

c) Look at our own reeds while at the same time respecting the rights of those around us.

2) Saying "NO" when you mean "YES" and assuming the other person knows what you are really thinking and feeling:

a) Usually happens as people become closer in a relationship and should be viewed as a positive way to commuicate.

b) Is likely to lead to difficulties in the relationship.

c) Is an assertive way to interact with someone you're close to.

3) Sexual harassment is:

a) Depends upon the effect it has or the response it evokes from another person.

b) Any look, gtare, comment or touch that has a sexual reference.

c) Is often a comment or look that has been miginterpreted by someone who is more sengitive to comments than the next person.

4) You have been in a relationship gince sophomore year in high school and are now about to graduate. On the weekend before graduation your date forces you into having sexual relations.

a) You should protect your relationship by not discussing the event.

b) Acknowledge that your relationship was violated and discuss it with a trusted adult.

c) Asoume that after an apology that the violation will not happen again.

5) If you are involved in a relationship in which abuse has occurred, you:

a) Stick with the relationship because it probably won't happen again.

b) Fight back and refuse to be intimidated.

c) Recognize the likelihood that the abuge will probably re-occur.

6) People who are victims of abuse:

a) Usually have done something to stimulate it.

b) Could have done thinga differently and it wouldn't have happened.

c) Under any circumstances, the responsibility lies with the person who does the abuaing.

7) Consent ig:

a) Active, not passive.

b) Giving in because of fear.

c) Going along with something because you want to fit in with the group. 
8) Once you know people fairly well, the begt way of commulating with them is to:

a) Verbaliy express your feelings.

b) Assume they know you well enough to know how you are feeling.

c) Find out how they are feeing about something, because chances are you will feei the same way.

9) Rape is a crime of:

a) Violence and power.

b) Sex.

c) Pasgion and uncontrolled feelings.

10) Sexual harassment most frequentiy occurs between:

a) People who realiy don't know each other.

b) Old and/or jealous girlfriends/boyfriends who you no longer with to be involved with.

c) It could happen in almost any situation.

11) The socialization process in our country produces:

a) Assertive men and passive wornen.

b) Assertive men and assertive women.

c) Aggressive men and passive women.

12) Approximately one-third of high school gtudents have:
a) Reported being assaulted to the authorities.
b) Gotten pregnant.
c) Been involved in an unwanted sexual experience.

13) Most rapes that occur are not by a gtranger but by someone the victim knows:
a) Thia is a true statement.
b) This is not a true statement.
c) In most cages, the rapigt is a stranger.

Rita Chrappa, M.A. 


\section{APPENDIX E}

\section{Great Expectations: Dating in High School}

\section{An Introduction}

Great Expectations is a sixty-minute workshop developed out of the awareness of the high percentage of "Acquaintance Rape" that occurs between the ages of eighteen and twenty-four years. It is a workshop aimed at educating students around expectations in dating relationships and around the importance of communication plays in the acknowledgement of expectations.

Because up until this point, little, if anything, has been done to help students to become aware of the differences and commonalities in expectations between men and women in relation to dating, it will be a major focus throughout this workshop. We would like to inform students about responsible dating by making them aware of their own feelings and values, as well as those of their peers.

It is also our intention to educate students around issues of "consent," as well as to help them gain an understanding of "sexual harassment" and resources available to them in times of stress.

We are not, I repeat, are not saying by any means all mean are bad, that all men are rapists, or that men don't care, but we are suggesting that we live in a society that perpetrates a rape culture. In the process of this workshop, we also hope to dispel many of the myths that our culture perpetuates, such as, "When a women says no, she means yes, etc."

The point to be made is that relationships can be gratifying, can be rewarding, and can be loving, but before we can get there, a lot of ground must be covered. The first place to start and what I think to be the best place to start: Expectations.

A note to presenters: It is important to keep in mind that although we are talking in general about dating relationships, the leaders should not assume that these relationships are always heterosexual. Considering that approximately ten percent of the population is homosexual, the chances of having some students who are homosexual is a high possibility. Therefore, although this workshop does not deal specifically with homosexual relationships, it is very important that they are respected.

This is a sixty-minute workshop that, if possible, should be run by both a male and a female. It appears to run smoothest when given to a group of twenty-five to thirty, mixed-sex students, although it can be given to up to eighty without much difficulty. 
Great Expectations: Dating and High School

Goals:

1. To help students to be able to identify and communicate their expectations for a dating relationship.

2. To help students become aware of their own feelings of comfort and discomfort in relationships.

3. To define for students "consent" and "sexual harassment."

4. To help students to become aware of the importance of negotiation and communication skills.

5. To help students understand that "assuming" is not a form of communication.

6. To dispel some myths related to men and women around dating.

7. To explain available resources to students.

* This workshop should, if at all possible, be run with both a male and a female leader.

At this point, the leaders should introduce themselves: names, where they work, and their interest in doing this workshop for students. (Because, as leaders, you will be working with a large group of students, it is not important to have them introduce themselves at this time. However, you may want to have them introduce themselves by their first names when they have a comment or a question).

* The whole introduction up to breaking into small groups should last between five and eight minutes.

I. Leaders should briefly discuss what will be covered in the workshop. A short opening is suggested as follows:

"As you all know, high school is usually a time when students begin to get interested in dating relationships. This is a very exciting time as well as a scary time. Relationships can be both productive and gratifying or destructive and hurtful. What we hope to accomplish by doing this workshop is to facilitate (help) the number of gratifying relationships and to decrease the number of hurtful ones." 
"We have all heard of the abusive relationship or seen them on TV or in the movies. Well, those same kinds of relationships can happen in high school as well as in college and after if we do not learn to communicate openly and honestly with one another. It is also important that as students you learn to know and respect you own feelings as well a those of your friends. We have found that one of the best ways to start to explore what dating relationships are all about is to have you begin to look at your own expectations."

\section{Exercise \#1}

Goals :

1. Brainstorm and generate lists of students" expectations in dating relationships.

* Note to the Leaders: It is important when working with your groups that the focus is on generating 1 ists and not on discussion. The discussion of the issues is valuable for the large group that follows.

2. The leader announces that the students will break into two groups, one with males and one with females, each having their assigned leader (male leader with male group, etc.). The leader should also make a statement that everyone is allowed his/her opinions or expectations. It is important not to judge responses, but to just 1 ist as many expectations as you can come up with. They will be discussed later in the larger group. The leader will also need to ask for a recorder to write down what is said and to report the list back to the large group.

Each group will answer the following questions:

1. Men's Group:

A. What do men say that men want out of dating relationships?

B. What do men say that women want out of dating relationships? 
2. Women's Group:

A. What do women way that women want out of dating relationships?

B. What do women way men want o out of dating relationships?

* Note to leaders: Most of the men's group says that men want sex first. It is important that this be treated as any other expectation, and that the group stays on task to allow other expectations to come out.

Most often, the women's group will say men expect sex first. However, they will often leave it until last as far as what women expect, or they may omit it all together. If sex is omitted, it is important to point it out as an expectation that is usually mentioned at some point.

Leaders should allow no longer than ten minutes for this exercise.

(Please refer to page 7 for a sample list of expectations as they might be seen during the large group discussion.?

3. Leaders now ask for the small groups to join one another and to mix up so that males and females are not separated.

Once the large group is settled down, the leader says the following: "What we are now going to do is take the lists that you have come up with in your groups and put them on this newsprint, so we can begin to look at some of the similarities and differences in what men and women expect in dating relationships." The leader should also make sure to mention the following two points: 1) We are all allowed our expectations. This is not a time for making fun of expectations. It is a time to look at them and to begin to understand that they do exist ( and that they have meaning in relationships). 2) We did not ask people to prioritize their expectations, so just because something is first or last on a list does not mean that all men or women think of one specific thing first and another last. 


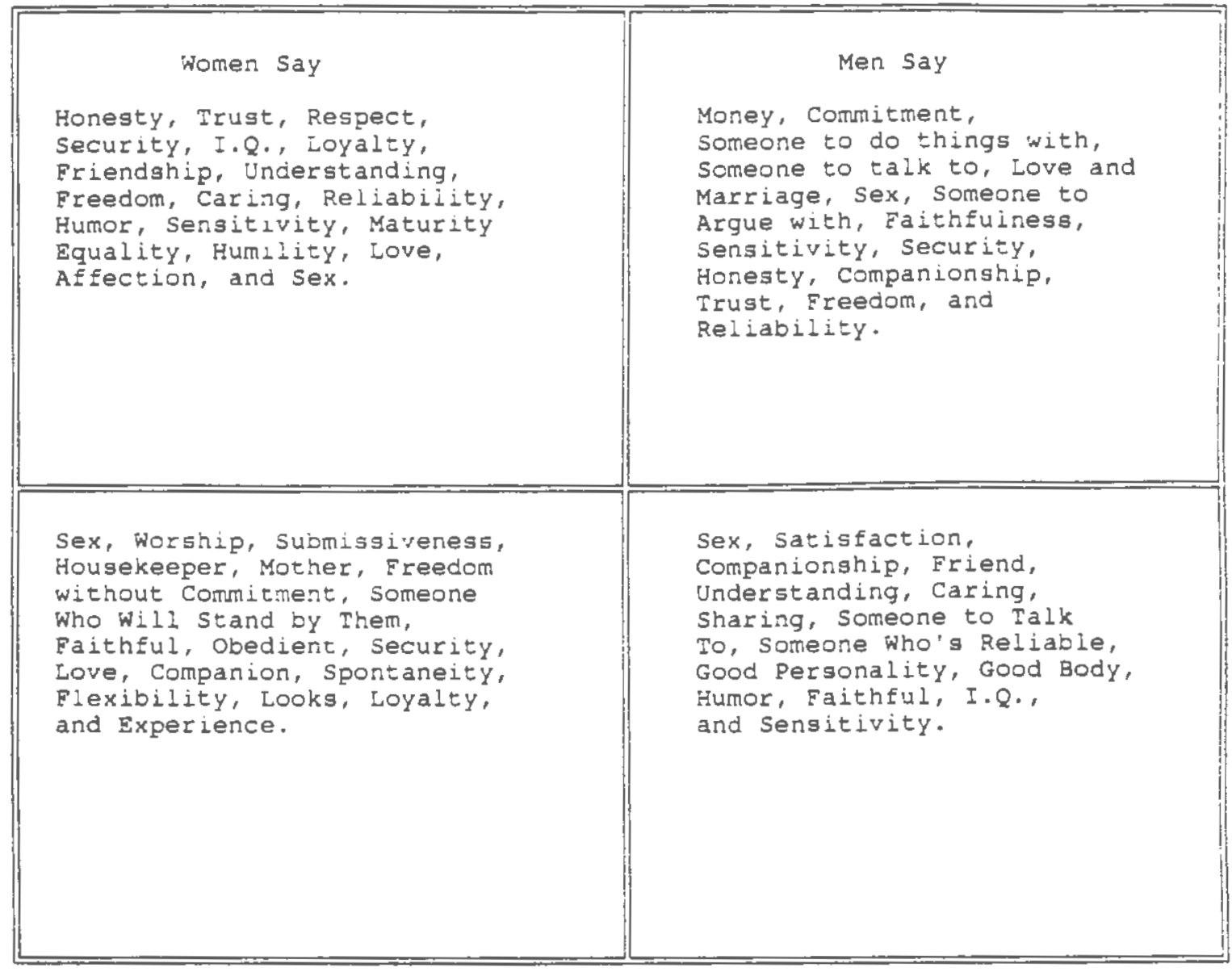

* This list was created by a group of eighty seniors entering college - Summer of 1986. 
In fact, if we were to hand you all paper and ask you to develop and prioritize lists on your own, we would get many, many, different lists.

1. Ask each group, alternating, to give their responses to the questions asked.

2. The leader should clarify or ask for clarification on any response that is not understandable.

3. Discuss differences/commonalities in the expectations given from the group.

The following discussion should help the leaders to address important areas:

While looking at the list of expectations completed on the newsprint, it is important to note that there realiy are not bad expectations, that all expectations can be okay if they are communicated verbally and are mutually agreed upon. Let us take, for example, "sex." At some point in a relationship, sex may become the expectation. However, if the man has sex first on his list and the woman has sex at the bottom of her list, then there is going to be some friction in the relationship, unless these expectations are communicated openly. If they are not, he might assume that because sex is first on his list, it is first on hers, and they might wind up in a situation where sex will occur without consent.

* Please be aware of the definition of "consent." It is important to remember in relationships that consent is based on choice. Consent is active, not passive. Consent is possible only when there is equal power. Giving in because of fear is not consent. If you cannot say, "no," comfortably, the "yes" has no meaning. If you are unwilling to accept a "no," then "yes" has no meaning. Although it is not necessary to give the students this exact definition, they should have a good grasp of the meaning of consent by the end of the workshop.

often it is found in relationships that after a certain period of time, one week, one month, one year, etc., that people assume what others might be thinking. How often do we hear statements such as, "Well, I thought that was what you wanted," or, "I figured that after having dated for so long that you wouldn't mind." What is happening in these relationships is that an assumption is being treated as a form of communication. An assumption or mind reading is not a form of communication. One should not assume that you know what another's expectations are. 
You might be wrong, thus, leading you into what might possibly turn into a destructive, hurtful situation. Expectations need to be communicated verbally and openly. (The point should be made, however, that this does not mean on the first date that you each pull out your Iists. Rather, it is a gradual process that should develop along with the relationship.)

In relationships, it is important that individuals are, first, aware of their own expectations, second, communicate these when the time arises, and third, listen to the expectations of others with the same respect they were given.

The point should also be made that expectations can change from one relationship to the next or within a particular ongoing relationship. Change is not bad as long as open communication is maintained.

Another point that should be covered in the course of the large group discussion is the role society plays in establishing certain norms for the different sexes. For example, most often there will be a comment about the men saying sex is first and the women putting last. It is important that we explain to the students that society's expectation for men is that when they are with a group of men and are asked what they expect out of a dating relationship, that "sex" is the manly thing to say. However, students should be aware that not all men would say that if asked individually, just as women would not always put sex last if asked individually. We live in a society that has raised men to be aggressive and women to be submissive, and one way of beginning to change these norms is by dispelling some of these myths in workshops such as this one.

Other points to be covered during the large group are as follows:

1) If expectations are not communicated or if they are not respected because of alcohol, violation is not excused. An individual's feelings should be respected and taken seriously. Alcohol should never be used as an excuse for violating another individual, either physically or psychologically. Statistics show that if one violation occurs due to alcohol (drug) usage, others are likely to follow. Most often, individuals who are abusive during high school continue to be abusive during college and then in marriage.

2) If expectations are assumed and sex happens without consent, this is termed "Acquaintance Rape." Often people wonder how, if it is a friend, you can call it rape. Yet, friend or no friend, if sex occurs without consent, it is a rape. 
3) If you are unsure about your expectations, it is important to take responsibility for yourself by "listening" to how you are feeling, i.e., comfort or discomfort. Often in situations, a student might say, "Well, I was feeling uncomfortable about what was happening, but I always heard about how nice this person was, so I decided to stay with him, and in the end, got hurt." If you are feeling discomfort, you should take the time for yourself to understand where the discomfort is coming from. If you then discuss this with your date, and your feelings are not respected, then you may want to get out of the situation before it is too late. on the other hand, if your feelings are taken serlously, and you are given the respect you deserve, it may be a sign of a good, open and gratifying relationship.

* It is important to listen to yourself, for unless we respect our own feelings, we cannot respect those of others, hor can we expect others to take us seriousiy.

4) It should be made clear to students that in all relationships, whether friendships or dating relationships, there are expectations. Although they may vary from one relationship to the next, the crucial point is to know that they exist, and that to have the most fulfiling and gratifying relationship, these expectations should be communicated in the process of the developing relationship.

* This is an important point, as we would like students to not only respect expectations in dating relationships, but in all relationships.

* Allow at least twenty minutes or more for this section.

4. Leaders now address the group in preparation for the last exercise.

III. Exercise \#2

Goals:

1. To give students the opportunity to explore various options and choices they have in response to a variety of situations. 
2. To give males and females an opportunity to hear how they might each respond to a particular situation and why they would respond that way.

3. To begin to familiarizing students with issues that might come up in a dating relationship.

4. To help students to begin to apply some of the basic concepts that were addressed earlier in the workshop.

* Note to the leader: This may be done in two mixed-sex groups, or if time does not allow, can be done in one large group. It appears, however, that the smaller the group, the better the participation on the students' part.

1. The leader announces that one of the things we have found to be helpful in discussing expectations and communication is to go over some difficult situations in which other students have found themselves. It is helpful when both the males and females participate, so you can begin to see the importance in understanding your own expectations, as well as respecting those of others.

Please break up into two groups with mixed sex.

2. The leader of each group now chooses at least two scenarios to go over, trying to pull responses from as many students as possible. The more the participation, the greater the value to the group.

* Note: Because, in the body of the workshop, we did not discuss sexual harassment, it is preferred that $\# 7$ be one of the scenarios used; this, allowing the opportunity for some discussion around this issue. The leaders may then choose scenarios that reflect some of the issues that come up throughout the workshop and/or ones that are of particular interest to the leader.

* Important points to keep in mind while going over the scenarios:

1. The importance of communicating expectations verbaliy. 
2. Assuming or mind reading is not a form of communication.

3. "Consent" is active, not passive. (Review definition.)

4. Listening to and respecting your feelings as warning signals for what may turn out to be a destructive or hurtful situation.

5. Rape is not only comitted by the scary man in the alley, but by anyone who does not get consent to have sex. Thus, coerced sex by an acquaintance = "Acquaintance Rape."

6. Men, as well as women, can be sexually harassed.

(Keep in mind the definition: "Any feeling of intrusiveness, lack of respect, or invasions of personal space which comes from another individual which makes you feel guilty, ashamed, or frightened.")

It is important in doing the 7 th scenario that students realize that if someone is not respecting their rights and is harassing them that giving into him/her will only perpetuate the harassment. Harassment is not respecting another's rights. The difference between men and women being harassed is that when a woman is harassed and it continues, she may also be at physical risk of rape. While harassment can be just as disturbing psychologically for men, they usually do not feel the physical risk that women do.

* Allow at least fifteen minutes for the scenarios.

IV. Leaders announce that time is up and everyone again returns to the large group. Leaders do a summary and mention resources available to students, if needed.

\section{Summary:}

The purpose of this workshop was to begin to make students aware that dating relationships can be both gratifying and hurtful. At a time when experiences you might have, and to increase the number of productive, healthy, and rewarding relationships. 
Please keep in mind the points we went over today, and remember that no one knows what you are thinking and/or feeling as well as you do. Respect your feelings and you knowledge of yourself. Think carefully about what it is that you're expecting out of a relationship. Know that you have the right to make your own choices, as well as the right to have your choices respected by others.

If the time should arise that you need help over any of the issues we have discussed here today, it is important that you speak to someone: counselor in your school, your parents, your minister, priest, or rabbi, or other professionals who are trained to work with adolescents around these issues.

Issues come up for both males and females, and one way of respecting yourself is by getting the help you reed when you need it, and now waiting luntil things get worse.

REMEMBER: NO ONE DESERVES TO BE VIOLATED!

Allow about five minutes for summary.

* Note to leader: At the end of the workshop, pass out the handout, "How to set Limits About Sex." Also recommend the book listed at the bottom of the handout, "No Is Not Enough: Helping Teenagers Avoid Sexual Assault," by Caren Adams, Jennifer Fay, and Jan LoreenMartin. 
GREAT EXPECTATIONS:

DATING IN HIGH SCHOOL

\section{$\underline{\text { Scenarios }}$}

The following scenarios are to be used to help students begin to think through situations that might possibly come up at some point. It also allows them the opportunity to hear how both males and females respond to a given situation.

1. Imagine that you are with a friend who begins to drink while driving.

How might you feel?

What might you say or do?

Would it be possible to prevent this kind of problem?

2. Imagine that it's the Monday morning after a terrific weekend with a boy/girlfriend you like. You went out on Friday night, Saturday night, and sunday afternoon, and you're feeling really great about the relationship. on your way to school, you see him/her talking with someone whom you don't know, and they seem to be joking and having fun in a special way, as if they are very close.

How might you feel?

What might you say or do?

What expectations do you have of someone whom you've dated more than once?

3. Imagine that you've just spent a wonderful day and evening with a girl/boy who expresses a desire to have sex with you. You hesitate while trying to focus on you own feelings of comfort or discomfort. In the meantime, he/she is coaxing you, saying, "We've had such a special day, this is the best time, the right time to have sex, don't you think?

How might you be feeling? 
Do you think a person should have sex because the other person wants to?

If he/she continues to make advances and the other gets frightened and says nothing, is that person giving consent to have sex?

What could be the consequences of saying, "Yes,". . . of saying "No?"

4. Imagine that your parents are away for the weekend. Feeling that you're old enough to take care of yourself, they have left you at home alone, leaving back-up numbers if you reed help. After going to a movie with your date, you ask him/her back, thinking it would be nice to just sit and talk, even though your parents have told you not to have anyone over. Minutes after you're there, you date starts to make advances that make you feel uncomfortable and scared.

What might you decide to say or do?

What might make you ask him/her to leave?

Could it mean anything special to invite your date home when you both know no one is there or will be coming home?

Are there any differences in how a girl or boy might feel in this particular situation?

Can you imagine how you might talk about expectations before extending (or accepting) such an invitation?

Could this be an at risk situation for a girl? How and why?

5. Imagine that you are very hurt and angry by something your boyfriend/girlfriend has said or done. As you try to explain your feelings to him/her, he/she appears uninterested in what you are saying, and you feel more and more misunderstood and frustrated.

What might you do next?

What might the person who is uninterested be feeling? 
What might be the most constructive thing to do?. . . the least constructive thing to do?

6. Imagine that your friend and his/her date are having an argument at a party you're attending. After one of them becomes highly obnoxious and insulting, the other attempts to move away. However, the obnoxious one grabs the other in a very rough way and continues to yell and scream.

What do you imagine each person might be feeling?

What do you think each person might do to improve the situation.. . to make it worse?

As a friend of the couple, what might you be feeling?

Is there anything you might do to help?

Does it make a difference whether it is the girl or the boy who is doing the pushing around? Why?

7. You are asked out on a date, but decline because you don't particularly like the person that asked you out. This individual continues to call you, meet you at school, and appears to be following you around, even though you've told him/her you are not interested in dating.

How might you be feeling?

Is this a form of sexual harassment? Why or why not?

Should you give in and go out once? why or why not?

Is this person respecting your rights? 
* At least two scenarios should be used. Hopefully, there will be erough time to do more. The scenarios appear to be very valuable, in that they are most often a favored part of the workshop, along with discussing the expectations.

Rita C. Chrappa, M.A., A.B.D.

Permission to use this workshop may be obtained by writing to:

Ms. Rita C. Chrappa, M.A., A.B.D.

Dedham Medical Associates

One Lyons street

Dedham, MA 02026 
1. Maintain your choices by having your own car or transportation, or knowing you can call your friends if needed.

2. Pay attention to how your feelings change. A situation may seem all-right at first, but then becomes uncomfortable.

3. Be prepared for pressure if dating someone who has a reputation for "Scoring."

4. Decide what you' 11 do if she/he starts to presoure you for more gexual contact than you're ready for or when you aren't interested.

5. Practicing assertive responses can make resisting group presbure easier.

6. Practicing making choices based on what you want. It is easier to resist presgure if you know what you like and don't like, what you want and don't want. Extend this practice to recognizing when you don't like the way someone acts around you -- even your boyfriend's or girlfriend's rew buddy.

7. : Practice regponses to being taken advantage of in little ways (Is it fair he always uses your notes?... " she borrowg your cloths?). It may not seem worth the trouble to make a point of these little ways people take advantage of you, but it is easier to avoid being taken advantage of in larger ways if you've practiced on less important issues first.

8. Make deciaions about how you want to be treated, and practice aticking by them. If being treated well is one of the expectations you have for a relationship, you will be less likely to accept bad treatment which might lead into sexual aggaul.

9. Assertivenegs is no guarantee that you won't find yourself in a difficult group gituation, so be prepared to take action when you're confronted with a problem.

10. Walk and act confidently; look directly at people. If you don't look afraid, others may be less likely to pick on you.

11. Just continue to do whatever you are doing and get through the situation.

12. Appeal to a friend who is part of the group for help.

13. Know your own feelings, so you can tell how much fear and discomfort is normal for you in parties and social gatherings and how much means it isn't an okay gituation after all and it's time to leave. Your friends may laugh and you may be afraid you'hl get into trouble at home, but your feelinga may be teling you you would rather not be there.

14. If there is physical violence toward anyone, leave without guestion.

15. If desperate, be prepared to be outrageous: break a window, yell to call attention to the situation, ring the doorbell, turn the music way up or off.

From: No Is Not Enough: Helping Teenagers Avoid Sexual Agsault by Caren Adams, Jennifer Fay and Jan Loreen-Martin (Impact Publishera, 1985). 


\section{Bibliography}

Abbey, A, (1982). Sex differences in attributions for friendly behavior: Do males misperceive females' friendliness? Journal of Personality and Social Psychology, 42, 830-838.

Adans, C., Fay, S., \& Loreen-Martin, J. (1985). No Is Not Enough: Helping Teenagers Avoid Assault. Impact Publishers.

Barnett, N.J., \& Field, H.S. (1977). Sex differences in university students' attitudes toward rape. Journal of College student Pergonnel, 18, 93-96.

Bell, R. (1980). Changing Bodieg, Changing Lives. New York: Random House.

Bolander \& Stodden. (Eds.). (1986). The Merriam-Webster Dictionary. Pocket Books.

Bordon, L.A., Karr, S.K., \& Caldwell-Colbert, A.T. (1988). Effects of a Univergity Rape Prevention Program on Attitudes and Empathy Toward Rape. Journal of College Student Development, 29, 132-136.

Botvin, G.J., \& Dusenbury, L. (1987). Life gkills training: A psychoeducational approach to substance-abuse prevention. In $C$. Maher \& J.E. Zins (Eds.), Psychoeducational interventions in the schoolg (pp. 46-65). New York: Pergamon.

Brownmiller, s. (1975). Against our will: Men, women, and rape. New York: Simon Schuster, 1975 .

Burkhart, B.R., S Stanton, A.L. (1985). Sexual aggression in acquaintance relationships. In G. Ruggell (Ed.)., violence in intimate relationships. Spectrum Press.

Burt, M.R. (1980). Cultural myths and supports for rape. Journal of Personality and Social Psychology, 38, 217-230.

Campbell, P. (undated). Are we encouraging rape? Georgia State University.

Check, J.V.P., Malamuth, N.M. (1983). Sex role stereotyping and reactions to depictions of stranger versus acquaintance rape. Journal of Personality and Social Psychology, 45, 344-356.

Clark, L., \& Lewis, D. (1977). Rape: The price of coercive sexuality. Toronto, Canada: The Women's Press.

Donnergtein, E., Berkowitz, L. (1981). Victim reactions in aggressive erotic films ag a factor in violence against women. Journal of Personality and Social Psychology, 4l(4), 710-724.

Ehrart, J.K., S Sandler, B.R. (1985). Campus gang rape: Party games? Project on the Status and Education of Women, Association of American Colleges. 1818 R. St., N.E., Washington, DC 20009.

Harrison, P.J., Downes, J., \& Williams, M.D. (1991). Date and Acquaintance rape: Perceptions and attitude change strategies. Journal of College student Development, 32, 131-139. 
Jenkins, M.J., \& Dambrot, F.H. (187). The attribution of date rape: Observer's attitudes and sexual experiences and the dating situation. Journal of Applied Social Psychology, 17, 875-895.

Kanin, E. (1969). Selected dyadic aspects of male sex aggression. Journal of Sex Research, 5, 12-28.

Kanin, E.J., \& Parcel1, S.R. (1977). Sexual aggression: A second look at the offended female. Archives of Sexual Behavior, $6,67-76$.

Kirkpatrick, C., \& Kanin, E.J. (1957). Male sex aggression on a university campus. American sociological Review, 22, 52-58.

Klemmack, S.H., \& Klemmack, D.L. (1976). The social definition of rape. In M.J. Walker \& S.L. Brodsky (Eds.), Sexual Assault. Lexington, MA: Heath.

Korman, S.K., \& Leslie, G.R. (1982). The relationship of feminist ideology and data expense sharing to perception of sexual aggression in dating. The Journal of Sex Research, 18, 114-129.

Koss, M.O., Gidycz, C.A., \& Wisniewski, N. (1987). The scope of rape: Incidence and prevalence of sexual aggression and victimization in a national sample of higher education students. Journal of Consulting and Clinical Psychology, 55, 162-170.

Koss, M.O., \& Oros, C.J. (1982). The Sexual Experiences Survey: A research instrument investigating sexual aggression and victimization. Journal of Consulting and Clinical Prychology, 50,
455-457.

Krulewitz, J.E. (1982). Sex differences in the evaluation of females and male victims' responses to assault. Journal of Applied social Psychology, 11, 460-474.

L'Armand, K., \& Pepitone, A. (1982). Judgements of rape: A study of victim-rapist relationship and victim sexual history. Personality and Social Psychology Bulletin, 8, 134-139.

Oros, C.J., Leonard, K., \& Koss, M.P. (1980). Factors related to self attribution of rape by victimg. Paper presented at the meeting of the American Psychological Association, Montreal, Canada.

Rapport, K., \& Burkhart, B.R. (1984). Personality and attributional characteristics of sexually coercive college males. Journal of Abnormal Psychology, 93, 216-221.

Schaps, E., Churgin, S., Palley, C.S., Takata, B., \& Cohen, A.Y. (1980). Primary prevention research: A preliminary review of program outcome studies. The International Journal of the Addictions, 15, 657-676.

Seligman, J., Huck, J., Joseph, N., Namuth, T., Prout, L., Robinson, T.L., \& McDaniel, A.I. (1984, April 9). The date who rapes. Newgweek, pp. 91-92.

Skelton, C.A. (1982). Situational and personological correlates of sexual victimization in college women. Unpublished doctoral dissertation, Auburn University, Alabama.

Sweet, E. (1985). Date rape: The story of an epidemic and those who deny it. Ms/Campus Times, pp. 54-85. 
Weis, K., \& Borges, s.s. (1973). Victimology and rape: the case of the legitimate victim. Issueg in Criminology, 8, 71-115.

Zins, J.E., Conyne, R.K., \& Ponti, C.R. (1988). Primary prevention: expanding the impact of psychological services in schools. School Psychology Review, 17, 542-549. 